\title{
A GLOBALIZÁCIÓS NYITÁS ÉS A MIGRÁCIÓS SZINTEK EMELKEDÉSE* Lépések egy globális történeti magyarázat felé
}

\section{Melegh Attila és Csányi Zoltán}

\section{ÖSSZEFOGLALÓ}

Fő kérdésfelvetésünk a globalizációs nyitásnak és a kapcsolódó társadalmi változásoknak a vándorlásra, illetve a vándorlási szintek és minták alakulását érintő hatásaira vonatkozik. Egy 77 országból álló globális mintán úgy végeztünk loglineáris regressziókat, hogy ezekből az 1990 és 1995 közötti időszak gazdasági-társadalmi változásainak, a nemzetközi migráció 1995-2000, 1995-2005 és 1995-2010 közötti alakulására gyakorolt hatásainak tekintetében vonhassunk le következtetéseket. Három elméleti megközelítést teszteltünk, mint a kumulatív okság, a modernizációs és a világrendszer-elmélet. Az egyes paradigmákhoz kötődő modellek mellett egy teljes, minden felhasznált jellemzőt tartalmazó, sokváltozós modellben is vizsgáltuk a folyamatokat. Kutatásunkat az időbeliséggel, a történetiséggel kapcsolatos kettős megközelítésünk teszi különlegessé. Egyrészt nem pusztán az egyes tényezők „azonnali” (keresztmetszeti) migrációs hatásaira voltunk kíváncsiak, hanem - korábbi irodalom alapján feltételezve, hogy e hatások időben eltolódva jelentkeznek - a vizsgálatunkat 5, 1015 éves időtávokon végeztük el. Másrészt - az eddigi kutatásoktól eltérően - az egyes változók adott időpontra vonatkozó abszolút értékei helyett azok különböző időintervallumokra vonatkozó növekményei kerültek kutatásunk középpontjába. Eredményeink szerint a kumulatív mechanizmusok (a migráció útfüggősége), a modernizációs folyamatok (a migrációs képesség növekedése) és a globalizációs nyitás egyes 
tényezőinek sokszor meglepő együttállása, konstellációja a meghatározó, miközben e tényezők hatása időben is változik, amely összefüggéseket egy több ponton módosítandó világrendszer-elmélet tud a legjobban integrálni.

Tárgyszavak: globalizáció, migráció, kumulatív okság, világrendszer-elmélet, modernizációs elmélet, külföldi tőkebefektetés

Melegh Attila, KSH Népességtudományi Kutatóintézet

Kommunikáció és Szociológia Intézet, BCE

E-mail:melegh@demografia.hu

Csányi Zoltán, Központi Statisztikai Hivatal

E-mail: zoltan.csanyi@ksh.hu

\section{BEVEZETÉS}

A globalizáció folyamatában az egyik legfontosabb elem a piaci nyitás, a szabadpiaci átalakulást szolgáló gazdaságpolitika és a tőke szabad mozgásának a biztositása (Czaika-de Haas, 2015; Harvey, 2005). E tekintetben az 1980-as évektől a 2010-es évekig tartó időszakot nevezhetjük a globalizációs nyitás időszakának, vagy történeti szempontból egy új globalizációs ciklusnak, amelynek az előrehaladtával a világ demográfiai folyamatai, különösen a migrációs folyamatok nagyon sajátos átalakulást mutattak, amit könnyedén összefüggésbe lehet hozni a globalizáció és a migráció körüli viták felerősödésével (Chase-Dunn et al., 1999, 2000). A globalizáció időszakában a migráció népességarányos szintje jelentősen megnőtt. Míg 1990-ben valamivel több mint 153 millió fő, a világ össznépességének 2,87\%-a élt a születési országán kívül, 2019-re ez a szám 271 millió fölé, 3,52\%-ra nőtt'. Globálisan nézve a vizsgált időszakban az elvándorló népesség körülbelül 78\%-kal emelkedett, és magasabb ütemben nőtt, mint a világ össznépességének a száma, amely ugyanezen periódusban lényegében a másfélszeresére gyarapodott.

\footnotetext{
'Az UN DESA International Migrant Stock és World Population Prospects adatai alapján. A gyorsulást megkérdőjelezi Czaika és de Haas, de munkájukban e szerzők az 1960 és 2000 közötti arányszámokat vették figyelembe, míg a mi elemzésünk az 1990 utáni időszakra vonatkozik (Czaika-de Haas, 2015).
} 
A globális elvándorlás arányának elmúlt évtizedeket jellemző gyorsuló ütemü növekedése olyan magyarázatot igényel, amely a globalizáció sajátosságain, illetve a földrajzi mobilitásra gyakorolt hatásain kívül figyelembe veszi a folyamat időbeliségét is. Ennek a vizsgálatához kutatásunkban három, egymással gyakran versengő, vagy éppen egymást kiegészitő, makroszintű vándorláselméleti paradigmát és azok főbb tényezőit empirikus eszközökkel, a nemzetközi elvándorlási szintekre gyakorolt hatásuk szempontjából vizsgáltuk. ${ }^{2}$

A migrációs elméletek csoportositásának egyik alapvető szempontja, hogy azok a vándorlási folyamatok elindulásával, vagy éppen a migráció önmagát gerjesztő, kumulatív mechanizmusaival kapcsolatosak (Massey, 1999; Massey et al., 1998). Ez utóbbi összefüggések kiemelt fontosságúak a vizsgálatunk szempontjából, hiszen a nemzetközi vándorlás az időbeliségét tekintve a globális világgazdaság szerves részeként annak egyszerre az oka és a következménye is. Ezzel összhangban az utóbbi évtizedek migrációs folyamatainak megértése sem lehetséges a kumulatív hatások figyelembevétele nélkül. Jelentőségének megfelelően a kumulatív okság képezi a kutatásunk egyik kiindulópontját.

A második, általunk kiemelt vándorláselméleti megközelítés szerint az elvándorlás szintje az adott ország gazdasági-társadalmi modernizációs átalakulásával, a modernizáció szintjével hozható összefüggésbe. A tranzíciós elméletek a modernizáció általános folyamatának részeként írják le a vándorlási folyamatok átalakulását és az el- és bevándorlási szintek változását (Zelinsky, 1971; de Haas, 2010a, 2010b). Ezen elméletek empirikus vizsgálatát nehezíti, hogy az átalakulási folyamat, a „modernség” mibenléte és mérhetősége körül nincs konszenzus.

A harmadik, a világrendszer-elméletekből ismert szempontrendszer tényezői az egyes országok piaci nyitásával, a globális és hierarchikus piaci gazdasági rendszerbe való belépésével, illetve ez utóbbiban betöltött strukturális helyével függnek össze (Massey, 1999; Sassen, 1988, 2006; Czaika-de Haas, 2015). Ezek vizsgálata során elsősorban a külföldi működőtőke beáramlás és a világkereskedelemben való részvétel mértékéből, a szabadpiac térnyeréséből, illetve ezen tényezőknek a kibocsátó országokra gyakorolt gazdasági-társadalmi hatásaiból indultunk ki.

Miközben a fő kérdésfelvetésünk az egyes paradigmákhoz köthető tényezők vándorlásra, illetve a vándorlási szintek és minták változására gyakorolt hatásaira vonatkozik, a jelenség komplexitásának és időbeliségének következtében a

${ }^{2}$ Az általunk is felhasznált tényezők és szempontok jó összefoglalását adja globalizációs hipotézisként Czaika és de Haas (2015, pp 284-86). 
fent említett elméletek számos tényező tekintetében fedik egymást. Egyéb támpontok hiányában úgy tủnik, hogy nehéz például annak az eldöntése, hogy a relatív jövedelmi szintek változását a migrációs folyamatokkal kapcsolatos hatásmechanizmusaik tekintetében a modernizációhoz, vagy éppen a világrendszer adott strukturális összefüggéseihez köthető magyarázótényezők közé soroljuk, hiszen mindkét elmélet megfogalmazhat hasonló feltevéseket. Ilyen például a közepes jövedelmi kategóriájú országok magasabb elvándorlási szintje. E probléma kiküszöbölésére - az egyes paradigmákhoz kötődő modellek mellett egy teljes, minden felhasznált jellemzőt tartalmazó, sokváltozós modellben is vizsgáltuk a folyamatokat, és külön figyeltünk arra, hogy az egyes közös változók a különböző modellekben mennyire illeszkedtek az adott tényezőegyüttesbe, és javult-e a magyarázóerejük.

Kutatásunkat az időbeliséggel, a történetiséggel kapcsolatos kettős megközelítésünk is különlegessé teszi. Nem pusztán az egyes tényezők „,azonnali” (keresztmetszeti) migrációs hatásaira voltunk kiváncsiak, hanem - korábbi irodalom alapján feltételezve, hogy e hatások időben eltolódva jelentkeznek a vizsgálatunkat 5, 10 és 15 éves időtávokon végeztük el (Sanderson-Kentor, 2008). Az eddigi kutatásoktól eltérően az egyes változók adott időpontra vonatkozó abszolút értékei helyett ezek különböző időintervallumokra vonatkozó növekményei kerültek a kutatásunk középpontjába. Ily módon a globalizáció kontextusában a nemzetközi migráció dinamikusabb látleletéhez jutottunk, amely a vándorlás folyamatainak a változásait az azokat magyarázni hivatott tényezők korábbi, referencia-időszakon belüli változásaival hozza összefüggésbe.

Főként az ENSZ-adatbázisok adatainak felhasználásával, összesen 77 közepes és nagy (azaz másfél milliónál több lakossal rendelkező) országból álló, és a nagyobb régiókat lefedő mintánkon úgy végeztünk log-lineáris regressziókat, hogy ezekből az 1990 és 1995 közötti időszak gazdasági-társadalmi változásainak, a nemzetközi migráció 1995-2000, 1995-2005 és 1995-2010 közötti alakulására gyakorolt hatásait illetően vonhassunk le következtetéseket. Eredményeink azt mutatják, hogy bár az egyes elméleti megközelítések mindegyike segíti a történeti változás megértését, mégis a globalizációs nyitásra koncentráló, a világrendszer-elmélethez köthető modell bír a legnagyobb magyarázóerővel, és ez a modell tudja a legjobban integrálni a más paradigmákkal közös tényezőket is. Tehát a kumulatív mechanizmusok (a migráció útfüggősége), a modernizációs folyamatok (a migrációs képesség növekedése) és a globalizációs nyitás egyes tényezőinek sokszor meglepő együttállása, konstellációja a meghatározó, amely összefüggéseket egy több ponton módositandó világrendszer-elmélet tud a legjobban integrálni. 


\section{ELMÉLETI MEGKÖZELÍTÉSEK ÉS KAPCSOLÓDÁSAIK}

\subsection{KUMULATÍV OKSÁG}

A migrációs szintek folytatólagos növekedésében az egyik legfontosabb tényező, hogy a migráció önmagát gerjesztő, kumulatív folyamat. Az elvándorlás már meglévő szintje kihat a további vándorlási folyamatok alakulására. A migráció hálózatos szerveződése - összhangban a társadalmitőke-elméletekkel - segíti az információ terjedését, a migrációs költségek csökkentését, a pszichoszociális problémák kezelését, és így újabb migrációs döntések megszületését. (Sik, 2011; Massey, 1999; Collier, 2013; Portes-Böröcz, 1989; Portes, 1995; Salmenhaara, 2009). A kumulatív okság egyben össze is épülhet a világrendszer-elemzésből következő tényezőkkel, hiszen az ott kiemelt migrációtörténeti kapcsolatrendszer felfogható a tartós történeti egyenlőtlenségek, a korábbi időszakok koloniális és migrációs kapcsolatainak hálózatos leképződéseként (Portes-Böröcz, 1989). Továbbá még a modernizációs tényezőkkel sem inkompatibilis, hiszen ez a megközelítés is azt hangsúlyozza, hogy az átalakulás öngerjesztő és önfenntartó folyamatokból áll.

A nemzetközi migráció folyamatait egyfajta intézményesedés is kíséri, ami szintén szerepet játszik a tömeges migrációs folyamatok fennmaradásában. Ezen institucionalista megközelítések szerint a vándorlással párhuzamosan kialakulnak annak formális és informális intézményi keretei, amelyek az egyes államok migrációval kapcsolatos jogszabályi, intézményi háttere mellett magukban foglalják többek között a bevándorlók beilleszkedését segítö ügynökségek, civil szerveződések vagy éppen az embercsempész-hálózatok létrejöttét is, amelyet Xiang és Lindquits a migráció infrastruktúrájának fejlődéseként írt le (Massey et al., 1998; Xiang-Lindquits, 2014).

Antropológiai megközelítésben a kumulativ okság részét képezi az elvándorlás kultúrájának kialakulása is (Klute-Hahn, 2007; Hárs, 2018). E bonyolult összefüggés szerint egyes társadalmak a vándorlókkal interakcióban alakítják ki az el- és bevándorlással kapcsolatos kulturális normákat és hiedelmeket. Az elvándorlás elfogadottsága vagy elutasítottsága, mint a korábbi történeti tapasztalatok kulturális kicsapódásai, illetve önmagában az a tény, hogy mennyire magasak a történetileg felhalmozódott migrációs szintek, komolyan kihathatnak a migráció további alakulására. Miközben e nehezen mérhető köztes hatások empirikus elemzése komoly akadályokba ütközik, az elvándorlás korábbi szintjeinek figyelembevételével mód nyílik a kumulatív okság - és az 
ennek kapcsán felmerülő, nem számszerüsíthető tényezők - kontrollálására. Az alábbi elemzés éppen ezt teszi, és a migrációs szint 1995 utáni változásainak esetében magyarázótényezőként veszi figyelembe az 1990 és 1995 közötti népességarányos elvándorlási szinteket.

\subsection{A MODERNIZÁCIÓS TÉNYEZŐK ÉS A MIGRÁCIÓS KÉPESSÉG NÖVEKEDÉSE}

A hetvenes években megjelent modernizációs-migrációs átmenetelméletek szerint a modernizáció általános folyamatának a részeként kell értelmezni a vándorlási folyamatok változásait (Zelinksy, 1971; de Haas, 2010a). E széles körü társadalmi változások magukban foglalják a mobilitási szintek növekedését és a migrációs mintázatok transzformációját is (például a nemzetközi vándorlásnak a belföldi vándorlással, vagy éppen a cirkuláris mozgásoknak a hosszú távú, letelepedési célú migrációval szembeni térnyerését). Jelen kutatásunkban az elvándorlási szintek változására összpontosítunk, és így azon modernizációs tényezők beazonositásával próbálkozunk, amelyek igazolhatják, hogy az adott értelmezési keretben fejlettebbnek minősülő államokat általában magasabb mobilitás jellemez, azaz modernségük részévé válik a szabadabb mozgás. Fontos megjegyeznünk ugyanakkor, hogy ezen elméletek egy része inflexiós pontként, „migrációs púp”-ként írja le a fejlettség/modernizáció egy meghatározott szintjét, amely felett a további fejlődés már nem az elvándorlás növekedésével jár együtt, hanem a bevándorlás növekedését és a migrációs minták átalakulását eredményezi (Faini-Venturini, 2008; de Haas, 2010a; Fassmann et al., 2014). Globálisan nézve a világ össznépességének arányában megadott elvándorlási ráta növekedése egyszerre köthető az azonos időben egyre nagyobb kibocsátást produkáló modernizálódó országok és a modernizáció előrehaladottabb szintjén álló országok migrációs aktivitásához.

Az általános modernizációs átalakulás lehetséges indikátorai között meg kell említenünk például a városiasodást, a mezőgazdasági munka háttérbe szorulását, az individualizációt, a jövedelemszintek emelkedését, a termékenység csökkenését, az írni-olvasni tudás és iskolázottság növekedését, vagy éppen az ezeket átfogó, komplex fejlődési indexeket (lásd például Human Development Index). Jelen elemzésben ezek közül csupán néhányat fogunk szemügyre venni, mielőtt más történeti változásokkal együtt többváltozós elemzésben tesztelnénk, hogy az e folyamatokban bekövetkező változások miként gyakoroltak hatást a migrációs szintekre. 


\section{Termékenység}

Zelinsky már a hetvenes évek elején felhívta a figyelmet arra, hogy - szemben a malthusiánus érveléssel - nem a magas termékenységből fakadó népességnyomás, hanem kontraintuitív módon, éppena termékenységcsökkenés teszi mobilabbá az emberiséget (Gosh, 1963; Zelinsky, 1971; de Haas, 2010a, 12, 27 , 30). Hein de Haas a migrációs átmenetek tesztelésekor ezt a hipotézist hosszú, több évtizedes időtáv beépítésével, az emigrációs szintek esetében többváltozós elemzésben igazolta is. Bár megjegyzendő, hogy mindezt nem tartotta oksági szinten értelmezhetőnek, és a háttérben meghúzódó valódi társadalmi okokra hívta fel a figyelmet, illetve emlékeztetett a változók közötti túl erős kapcsolatra, a multikollinearitásra.

1. ábra: A teljes termékenységi arányszám és az elvándorlási arány a világon, 1990-2019

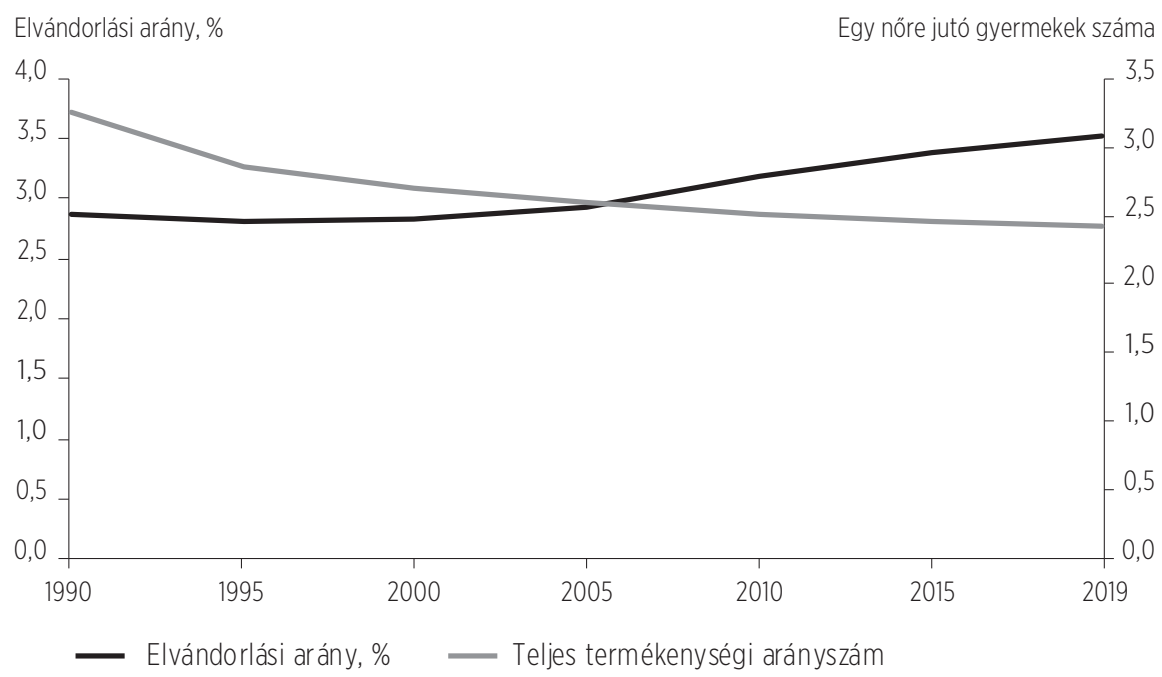

Forrás: saját ábra az ENSZ Gazdasági és Szociális Ügyek Főosztálya (UN DESA) népesedési adatbázisai alapján (https://www.un.org/en/development/desa/population/publications/database/index.asp).

Az 1. ábra mutatja a globalizáció korában, a világ egészében a teljes termékenységi arány és az elvándorolt állomány népességen belüli arányának az alakulását. Feltételezhető, hogy a termékenység csökkenése a mögötte álló folyamatok - a rurális szektorok hosszú távú visszaszorulása, az iskolázottság, különösen a nők képzésének előrehaladása - révén a népesség mobilitását is megnövelte. Ehhez az átalakuláshoz a városba áramlás, a nők falusi hatalmi szerkezetek aló- 
li felszabadulása is hozzájárulhatott (Demény-McNicoll, 2006; de Haas, 2010a; Wilson, 2001; Sen, 1999). Megjegyezzük, hogy a modernizációhoz kapcsolható fenti tényezőegyüttes nemcsak egy általános társadalmi átalakulás folyamatát mutatja, hanem fontos szerepe lehet a történeti-strukturális alapon érvelő világrendszer-elméletek szempontjából is, amelyek a kapitalista piacgazdaság és a piacosodás hasonló irányú társadalomalakító szerepét hangsúlyozzák.

\section{Az egy före jutó GDP}

A világgazdaság növekedése messze meghaladja a népességnövekedés mértékét. A 2. ábrán megfigyelhetjük, hogyan viszonyult egymáshoz 1990 és 2019 között a világ egy före jutó GDP-jének³ növekedése (2015-ös konstans USA dollárban kifejezve) és a globális migrációs ráta alakulása. Jól látható, hogy a 2000-es évektől a két változó igen hasonló dinamika szerint alakult. Feltételezhető, hogy a jövedelemszint abszolút értelemben vett növekedése is szerepet játszott a migrációs szintek emelkedésében, hiszen ez teszi lehetővé, hogy egyre több és több ember kifizethesse a földrajzi mobilitás költségeit, amennyiben ez utóbbiak nem növekednek a jövedelmeknél gyorsabban (Xiang-Lindquits, 2014).

A jövedelmi szintek abszolút változása mellett a modernizációs elméletek egy további tényezője a jövedelmek egymáshoz viszonyított, relatív alakulása és a jövedelmek esetleges konvergenciája. ${ }^{4}$ Miközben a globalizáció korában egyértelműen nőtt a nemzetközi vándorlás intenzitása, a relatív jövedelmek alakulásának vizsgálata és értelmezése szempontjából a következő forgatókönyvek lehetségesek. Amennyiben az országok közötti jövedelmi egyenlőtlenségek csökkentek, azaz globálisan az egy főre jutó GDP-k konvergenciája figyelhető meg az adott időszakban, akkor egy általános modernizációs átalakulás jelenlétét feltételezve következtethetünk a modernizációs elméletek helytállóságára. Amennyiben a vándorlási szint emelkedése növekvő globális jövedelemegyenlőtlenségek mellett következett be, akkor inkább a strukturális, pl. a világrendszer-elméletek által adott magyarázatok alkalmazhatósága tünik az elfogadhatóbbnak.

\footnotetext{
${ }^{3}$ Habár, mint ahogy Skoglund és Csányi (2019) rámutattak, a háztartások egy före jutó, rendelkezésrea áló jövedelmének alakulása nem feltétlenül követi az egy före jutó GDP változásait, jelen dolgozatban feltételezzük, hogy ez utóbbi alkalmas a tényleges gazdasági jövedelmek alakulásának az illusztrálására.

${ }^{4}$ Meg kell jegyeznünk, hogy nyíltan vagy burkoltan szinte mindegyik migrációs elmélet a jövedelmi egyenlötlenségek alakulásában látja a vándorlás egyik fő mozgatórugóját (de Haas, 2010a, 14). A szerepükkel kapcsolatos egyik leggyakoribb kritika, hogy nem annyira a tényük, mint inkább a velük kapcsolatos percepciók határozzák meg az egyéni vándorlási döntések kimenetelét. Az emberek általában tisztában vannak az egyes országok fejlettsége közötti különbségekkel (Thornton, 2012; Melegh et al., 2013, 2016). Ennek értelmében vizsgálatunk során eltekintettünk az egyéni percepciók vizsgálatától.
} 
2. ábra: Az egy före jutó GDP (2015-ös konstans USD) és az elvándorlási arány a világon, 1990-2019

Elvándorlási arány, \%

2015-ös konstans USD

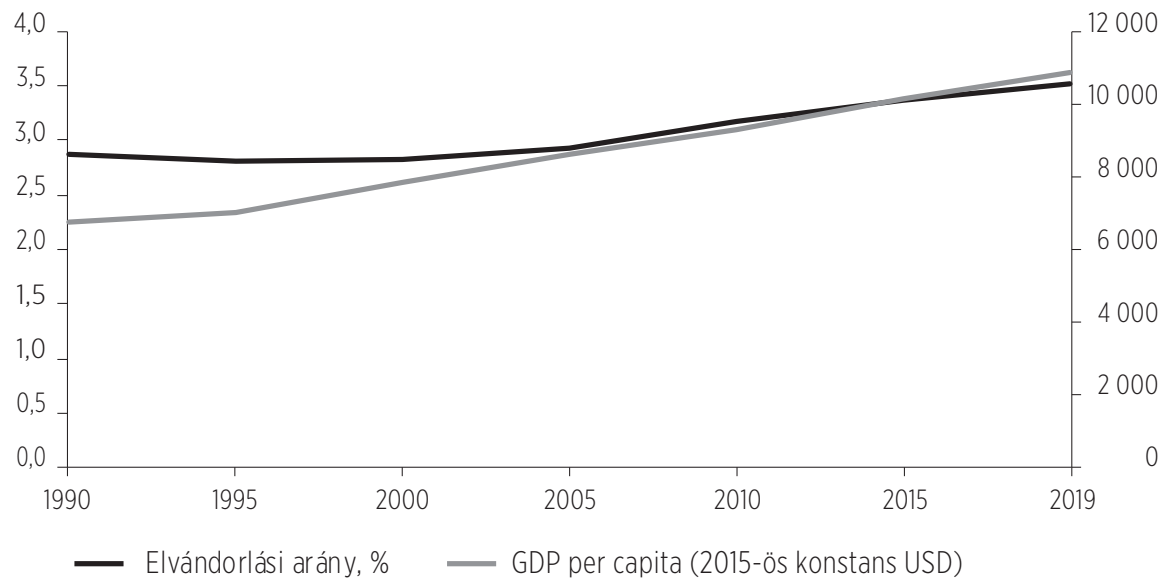

Forrás: saját ábra az ENSZ Gazdasági és Szociális Ügyek Főosztálya (UN DESA) népesedési adatbázisai (https://www.un.org/en/development/desa/population/publications/database/index.asp) és az ENSZ Kereskedelmi és Fejlesztési Konferencia (UNCTAD) adatbázisa alapján (https://unctadstat.unctad.org/EN/).

Az egyes országok egy főre jutó GDP-jének világátlaghoz mért arányából következtethetünk azok egyenkénti relatív jövedelmi pozícióira is. Ezek vizsgálatánál az előző bekezdésben bemutatott globális szintű megfontolásokkal szemben a következő migrációelméleti összefüggésekkel kell számolnunk:

- amennyiben a megfigyelt országok relatív jövedelmi pozíciójának javulásával együtt lineárisan növekszik az elvándorlás, úgy a modernizációs elmélet általában igaz, hiszen a relatíve javuló migrációs képesség növekvő elvándorláshoz, globális munkaerőpiaci aktivitáshoz vezet.

- Ha a jövedelmi pozíció javulása nincs pozitív lineáris kapcsolatban az adott ország elvándorlási arányának változásával, hanem jövedelemkategóriánként eltérően alakul, és a közepes jövedelmi kategóriában nő leginkább az elvándorlási arány, akkor a migrációs púp elmélete tünik igazolhatónak. Ki kell emelnünk azt is, hogy amennyiben az elvándorlás bizonyos jövedelemkategóriákhoz köthető, akkor az ilyen helyzetek leírására a strukturalista, világrendszer-elméletek is alkalmazhatóak, hiszen mind a púp-, mind a világrendszer-magyarázatból arra következtethetünk, hogy a legmagasabb elvándorlási arány a nem túl szegény és nem túl gazdag, közepes jövedelmü, azaz a félperifériás országokhoz köthető (Melegh, 2013a, 2013b; de Haas, 2010a, 2010b). Abban az esetben, amikor az elvándorlás növekedése romló relatív jövedelmi pozíció mellett következik be, vagy a 
jövedelmi pozíció vesztésére nem következik be komolyabb elvándorlási hullám, akkor valószínűleg helyesebb alternatív elméletek interpretációs lehetőségeire támaszkodni.

3. ábra: A világ országainak egy före jutó GDP-ben mutatkozó egyenlötlensége: az átlagtól való átlagos eltérés abszolút (2015-ös konstans USD) és relatív (\%) mértéke

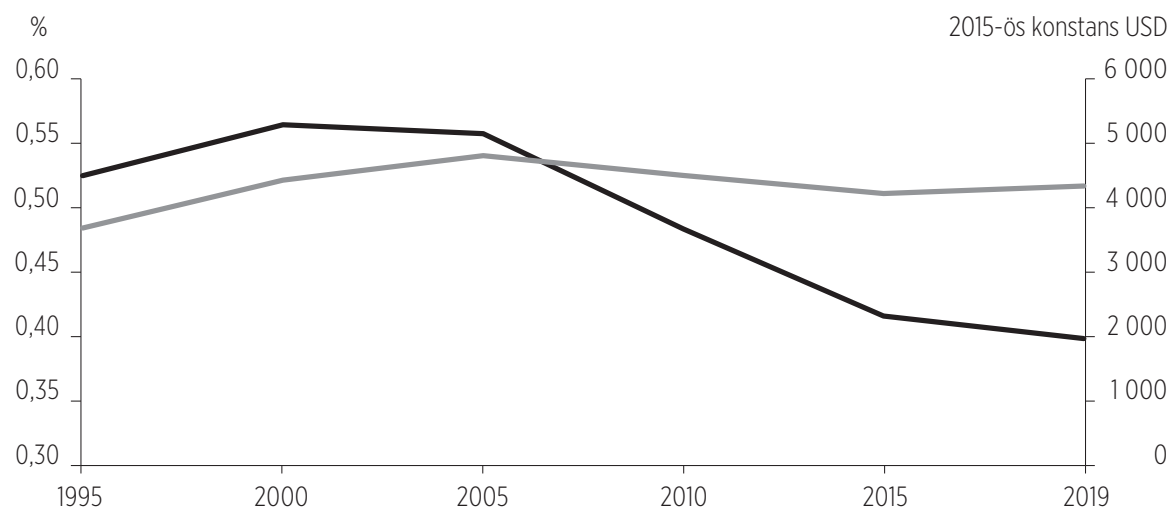

— Átlagtól való átlagos eltérés (a világátlag arányában kifejezve), \%

— Átlagtól való átlagos eltérés (2015-ös konstans USD)

Forrás: saját ábra az ENSZ Kereskedelmi és Fejlesztési Konferencia (UNCTAD) adatbázisa alapján (https://unctadstat. unctad.org/EN/).

A 3. ábrán a világ országainak egy főre jutó GDP-jében mutatkozó egyenlőtlenségek abszolút és relatív mértékét láthatjuk. A vizsgált időszak első szakaszában mind a relatív, mind az abszolút eltérések növekedtek. Ezt követően a relatív eltérések előbb kismértékben, majd 2005-től jelentősen csökkentek, miközben az átlagos abszolút eltérések egészen 2005-ig lassan növekedtek, azt követően pedig lassan csökkenni kezdtek. A népességhez viszonyított globális migrációs szintek is a 2005-öt követő években lódultak meg. Ebből kétféle következtetést vonhatunk le: az első szerint az egyenlőtlenségek relatív növekedése nem, míg annak csökkenése a migráció azonnali, népességarányos növekedését idézi elő. Ez pedig a modernizációs hipotéziseket látszik erősíteni: a globális gazdasági növekedés - amennyiben konvergenciával jár együtt - egy általános modernizációs folyamat révén megnövelheti az emberek mozgási képességét. A második lehetséges következtetés szerint, a strukturalista elméletek alapján a jövedelmi egyenlőtlenségek növekedése késleltetve fejti ki a hatását, és mintegy tízéves időbeli csúszással kell számolnunk. 


\section{Iskolai végzettség}

A demográfiai viselkedés szempontjából a modernizációs összefüggések között kiemelt helyet foglal el a humán tőke, azaz az átlagos iskolai végzettség növekedése. A termékenységgel kapcsolatos érvelésünknél is hangsúlyoztuk e tényezőt, különösen a nők körében. A migrációval kapcsolatos közvetett hatása miatt már Zelinsky (1971) is felhívta a figyelmet arra, hogy az iskolázottság növeli a migrációhoz szükséges információk megszerzésének a képességét. Az iskolában töltött évek globális átlagát a nemzetközi vándorlás kontextusában ábrázoltuk a 4. ábrán. Jól megfigyelhető, hogy miközben a migrációs szintek növekedése megállt és stagnált az 1990-es években, addig az iskolázottsági szintek már jelentős emelkedésnek indultak. A két trend a 2000-es évektől mutat azonos dinamikát, felvetve e két globális folyamat asszociációjának a lehetőségét.

\section{4. ábra: Az iskolában töltött évek átlagos száma és az elvándorlási arány a világon, 1990-2019}

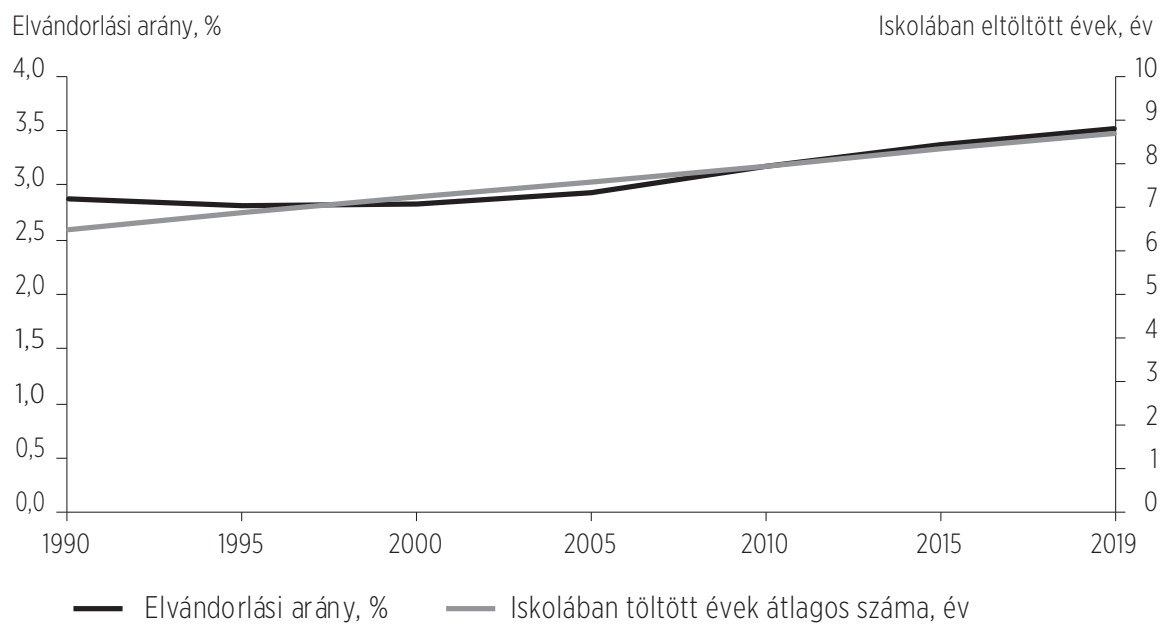

Forrás: saját ábra az ENSZ Gazdasági és Szociális Ügyek Főosztálya (UN DESA) népesedési adatbázisai (https://www.un.org/en/development/desa/population/publications/database/index.asp) és a Wittgenstein Centre Human Capital Data Explorer alapján (http://dataexplorer.wittgensteincentre.org).

\section{A mezőgazdasági foglalkoztatottság}

A modernizációs elméletek egyik központi eleme a rurális rendszerek leépülése, a paraszti világ felbomlása, és a lakosság városokba áramlása, amely folyamatoknak óriási jelentőséget tulajdonítanak nemcsak a társadalmi és demográfiai visel- 
kedés terén, hanem a mobilitási szintek emelkedésében is (Zelinsky, 1971; de Haas, 2010a). E tényező a világrendszer-elmélet esetében is kulcsfontosságú, hiszen a kapitalizmus megjelenése éppen az agrárfoglalkoztatottság átalakulásával és a bérmunka elterjedésével szakítja ki az embereket a lokális társadalmi-gazdasági rendekből, és teszi őket mobilabbá. Globális szinten a két folyamat ollószerüen követi egymást, azaz az agrárfoglalkoztatottság csökkenését nagyon pontosan, inverz módon leképezi a migrációs szint növekedése (lásd 5. ábra).

5. ábra: A mezőgazdasági foglalkoztatottság és az elvándorlási arány a világon, 1990-2019

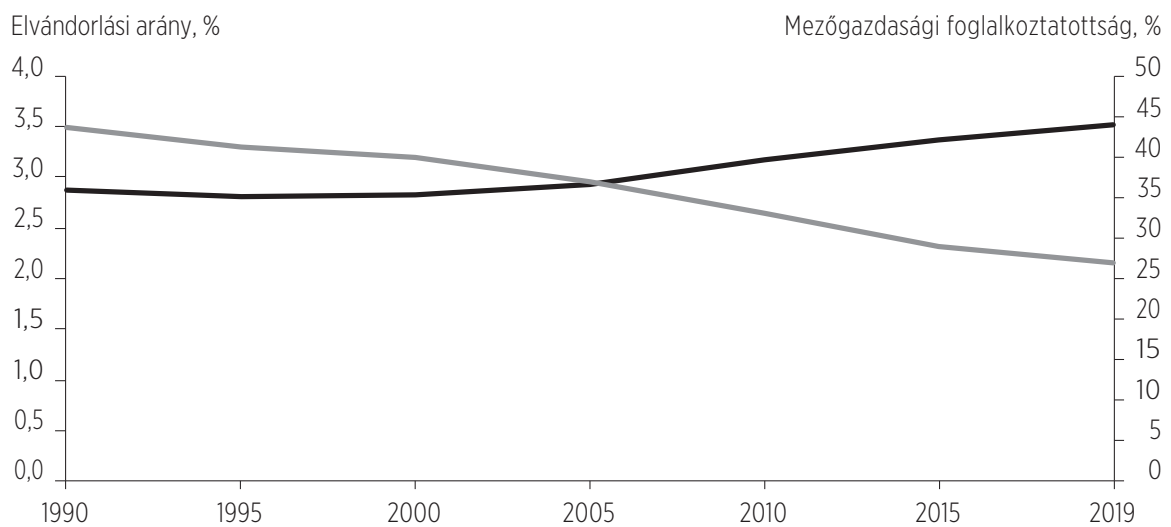

— Elvándorlási arány, \%

— Mezőgazdasági foglalkoztatottság aránya a teljes foglalkoztatott népességben, \%

Forrás: saját ábra az ENSZ Gazdasági és Szociális Ügyek Főosztálya (UN DESA) népesedési adatbázisai (https://www.un.org/en/development/desa/population/publications/database/index.asp) az ENSZ Kereskedelmi és Fejlesztési Konferencia (UNCTAD) adatbázisa alapján (https://unctadstat.unctad.org/EN/).

\subsection{A GLOBALIZÁCIÓS NYITÁSSAL ÉS A VILÁGRENDSZER- ELMÉLETTEL ÖSSZEFÜGGÉSBE HOZHATÓ TÉNYEZŐK}

Szintén a hetvenes években jelentek meg a migráció történeti-strukturalista, a világrendszer-elméletre épülő magyarázatai, amelyek a világ strukturális egyensúlytalanságainak és a piaci folyamatok térnyerésének a vándorlási folyamatokra gyakorolt döntő hatását emelik ki. Ezek értelmében a migrációs szintek emelkedése - a globalizáció kontextusában - a piacgazdasági nyitás és a hozzá kapcsolódó intézmények megjelenésének a következménye (Massey, 1999). Ez a piaci behatolás magában foglalja mind a kapitalista világrend térnyerését, mind az egyes országok- 
nak a globális piacokra történő belépését és a tőke szabadabb mozgását. Ezeknek az egyes társadalmakon belül bekövetkező, igen összetett hatásai révén átalakul a vándorlási folyamat, illetve új vándorlási mintázatok jönnek létre. Fentebb - mintegy utalásul az egyes paradigmák közötti átfedésekre - a modernizációs tényezők tárgyalásánál több helyen is kitértünk arra, hogy a modernizációs tényezők egy része, elsősorban a jövedelmek és a mezőgazdasági foglalkoztatottság alakulása jól értelmezhető a világrendszer-elmélet keretein belül is. Emiatt a jelen alfejezetben csak olyan tényezőket sorolunk fel, amelyekről az eddigiekben nem esett szó.

\section{A piaci nyitás és a tőke szabadabb mozgása}

A politikai-demográfiai helyzet történeti változása és a migrációs szintek emelkedése összekapcsolható a globális gazdaság nyitási (globalizációs) ciklusának más elemeivel is. Amennyiben a GDP-összértékre rávetítjük a viszonylag jól számba vehető külföldi közvetlen tőkebefektetések értékét (FDI), akkor ez az arány ciklikusan változott 0,5 és 10\% között (Chase-Dunn et al, 1999, 2000; Solimano-Watts, 2005). A legutóbbi emelkedési ciklus az 1970-es évektől indult meg. Ez az indikátor már csak azért is fontos lehet a számunkra, mert a migráció világrendszer-elmélete szerint a külföldi tőke nagyobb arányú megjelenése olyan folyamatokat indít el, amelyek összességében emelik az elvándorlás intenzitását.

A globalizáció és az új nemzetközi munkamegosztás következtében a gazdasági tényezők kapcsolódási rendje és a gazdasági integráció megváltozik a piacosodó térségben (Sassen, 1988,2006; Czaika-de Haas, 2015). A korábbi gazdasági és munkastruktúra összeomlik, a paraszti tömegek felbomlásával felerősödik a bérmunkássá válás folyamata, a hagyományos mezőgazdasági önfoglalkoztatás lecsökken (lásd 5. ábra). Az agrárszektor kommercializálódik, növekszik a vidékről városba áramlás, és az így előálló munkaerőpiaci feszültségek szétterjednek az adott országban. Jelentősen emelkedik a nők ipari foglalkoztatottsága a betelepülő tőke által is generált új iparosodás folyamatában. Ez, amennyiben növeli a munkanélküliséget a férfiak között, elvándorlást eredményezhet az utóbbiaknál, akik a rosszul jövedelmező agrármunka helyett a patriarchális viszonyoknak is jobban megfelelő elvándorlás mellett dönthetnek. Továbbá, a befektetések révén közvetlen szervezeti munkakapcsolatok jöhetnek létre a külföldi vállalatokkal, amelyek hozzájárulnak a kulturális, ideológiai kapcsolatok megerősödéséhez, illetve a fogyasztási szokások globális elterjedéséhez. Megjegyzendő, hogy a Kelet-Európában, Ázsiában és Közép-Amerikában létező ipari, nemkapitalista rendszerek is részben sajátos, ugyanakkor részben hasonló átalakuláson mehettek át a tőke szabad mozgásán alapuló piacgazda- 
ságokra való áttéréssel, az ottani gazdasági és munkaviszonyok összeomlásával (Melegh, 2013b; Melegh-Sárosi, 2016). Globális szinten ez volt az adott időszak talán legnagyobb jelentőségű átalakulása.

Könnyen belátható, hogy a külföldi tőkebefektetések szintjének és súlyának emelkedése előtt olyan intézményi és gazdaságpolitikai változtatásokra van szükség, amelyek a tőke beáramlását lehetővé teszik. Ez pedig a nyitásnak megfelelő pénzügypolitikát, a nemzeti és a külföldi árak összekapcsolását, a nemzeti szubvenciók leépítését, a nemzeti versenytárscégek felvásárlását, és a tulajdonosi profit esetleges kivételét jelenti (Harvey, 2005, pp. 2-4). Az ilyen változás különösen éles fordulatot jelenthet az olyan országokban, ahol korábban ez a „védettség” nagyobb volt, vagy éppen nem rurális, hanem ipari, nemkapitalista gazdasági rendszer volt uralmon, mint például a szocialista blokkban. Tehát a külföldi tőkebefektetések megjelenése előtt is már van egy globalizációs, a gazdaságot alapjaiban átalakitó előkészitő szakasz (Melegh, 2013b; Melegh-Sárosi, 2016). A migrációs szakirodalom kifejezésével „gyökérvesztésről”, Polányi Károly szavaival „kiágyazásról” beszélhetünk (Block, 2001). A döntéshozók a piaci viszonyok érvényesítése miatt leépítik az adott csoportok stabilabb és nem piaci kapcsolatokon alapuló társadalmi védőhálóját. Ekkortól nőhet meg a migráció intenzitása, habár e hatás kibontakozása időbe telik. Azt is fontos látni, hogy amint a külföldi tőke, vagy az azt szolgáló gazdaságpolitika már részben „kiágyazta” a vonatkozó csoportokat, megingatta a korábbi helyi struktúrákat, akkor megindulhat a migráció, és e folyamata már követheti a saját autonóm kumulatív oksági folyamatait is a globális egyenlőtlenségi rendszerekben. Összefoglalva, ezen elmélet szerint a globalizáció következtében a tömeges migráció strukturális feltételei változnak meg, azaz a globális gazdasági nyitás közvetett módon, időbeli késleltetéssel fejti ki a hatását a migrációs folyamatokra.

Sanderson és Kentor (2008) többváltozós elemzéssel igazolta ezt az időbeli csúszást. Egy szűkebb mintán és egy korábbi időszakra vonatkozó elemzésükben kimutatták mind a külföldi müködőtőke GDP-arányos felhalmozott szintjének, mind az évenkénti beáramlásának a fejlődő országok 10-15 évvel későbbi vándorlási egyenlegére gyakorolt hatását. Megjegyezzük, hogy a szerzőpáros szerint a beáramlás rövid távon pozitív irányba tolta le a korábban negatív vándorlási egyenlegeket, és csak a külföldi tőke állományi szintjeinek (tőkeállomány/GDP) növekedése mozdította a vándorlási egyenleget negatív irányban. Az általuk is elemzett összefüggéseket a 6. ábrán ábrázoltuk globálisan, 1990 és 2019 között. Jól látható, hogy az 1980-as évek közepétől a külföldi tőke beáramlásának a szerepe jelentősen megnőtt a világban, majd az 1990-es évek végén és a 2000-es évek második felének válságáig újabb és újabb nekilódulásnak lehettünk a tanúi. 
Azt is láthatjuk, hogy némileg később a globális elvándorlási szint is emelkedik. Tehát felvethető egy késleltetett kapcsolat a tőkeáramlás és a migráció között, amit az alábbiakban majd igazolunk is.

6. ábra: Az elvándorlási arány és a külföldi müködőtöke beáramlásának (6.1. ábra), illetve a felhalmozott szintjének (6.2. ábra) 10 évvel korábbi, GDP-arányos szintje a világon, 1990 (1980)-2019 (2010)

\section{1. ábra}

Elvándorlási arány, \% Tökebeáramlás a GDP \%-ban

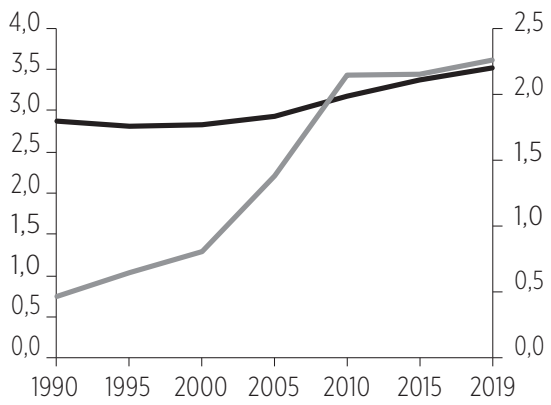

— Elvándorlási arány, \%

— GDP arányos működőtőke beáramlás mozgóátlaga (10 évvel korábban), \%

\section{2. ábra}
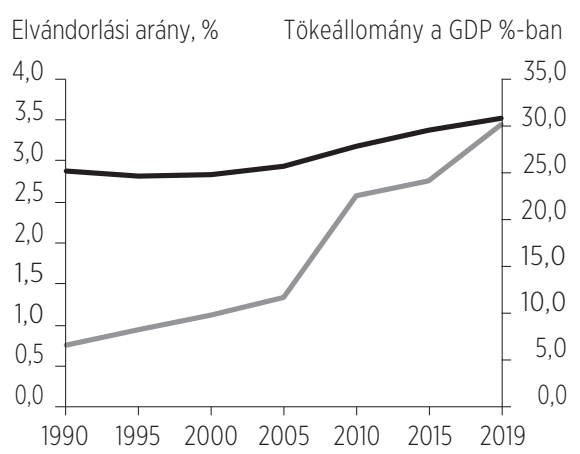

— Elvándorlási arány, \%

— GDP arányos működőtőke állomány (10 évvel korábban), \%

Forrás: saját ábra az ENSZ Gazdasági és Szociális Ügyek Főosztálya (UN DESA) népesedési adatbázisai (https://www.un.org/en/development/desa/population/publications/database/index.asp) az ENSZ Kereskedelmi és Fejlesztési Konferencia (UNCTAD) adatbázisa alapján (https://unctadstat.unctad.org/EN/).

\section{Export}

A világrendszer-elmélet a migráció emelkedését összeköti az exportorientált ágazatok növekedésével, amelyek főképp a mezőgazdaságban indítottak el jelentős munkaerőpiaci folyamatokat (Sassen, 1988,2006). Ezért Chase-Dunn et al. $(1999,2000)$ kereskedelmi globalizációs, azaz GDP-arányos importmutatójának mintájára az elemzést elvégeztük az export GDP-hez viszonyított arányára nézve is. Ez az összefüggés a gazdasági nyitottság, a kereskedelmi globalizáció révén közvetett formában, éppen a „kiágyazási” folyamatok révén érvényesülhet (Stalker, 2000). Sőt, mint azt a 7. ábrán láthatjuk, a vándorlási arány és az export rátája összességében - a világrendszer-elmélet érvelésének ellentmondva - eltérő dinamikákat követett az elmúlt évtizedekben: az 1990-es években a vándorlás növekedése stagnált, miközben az export révén mért gazdasági nyitottság egyre nőtt. Ezzel szemben 2005-től a két folyamat dinamikája éppen ellenkezőképpen alakult. 
7. ábra: A GDP-arányos export és az elvándorlási arány a világon

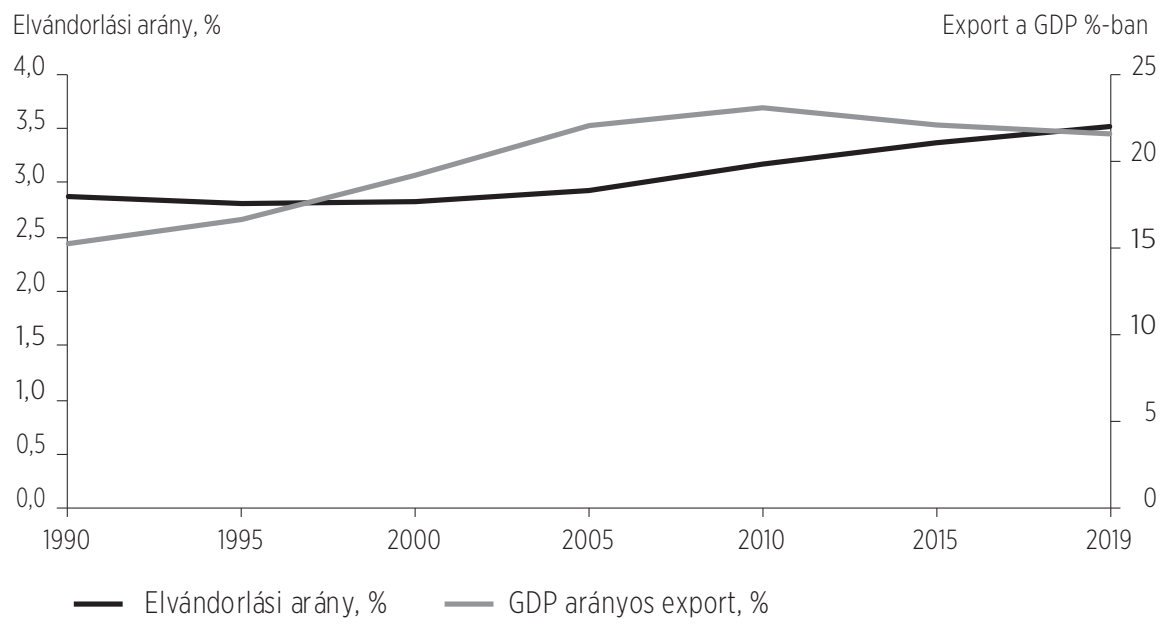

Forrás: saját ábra az ENSZ Gazdasági és Szociális Ügyek Főosztálya (UN DESA) népesedési adatbázisai (https://www.un.org/en/development/desa/population/publications/database/index.asp) és az ENSZ Kereskedelmi és Fejlesztési Konferencia (UNCTAD) adatbázisa alapján (https://unctadstat.unctad.org/EN/).

\section{TÖBBVÁLTOZÓS TÖRTÉNETI MODELLEK KIDOLGOZÁSA}

Az elemzés legfontosabb kérdésfelvetése a globális elvándorlási arány növekedésének komplex történeti magyarázata: a globalizáció kezdeti időszakának mely gazdasági-társadalmi változásai fejtettek ki szisztematikus hatást a későbbi időszakokban a teljes elvándorolt állomány változására az adott országok össznépességének arányában kifejezve. Bár az elemzés során Sanderson és Kentor (2008) elemzése több szempontból is irányadó volt, kutatásunk nagyban eltért ettől. Míg a fent említett szerzőpáros az 1985 és 2000 közötti időszakot vizsgálta, mi az 1990 és 2010 között eltelt évtizedekre összpontosítottunk. Ennél fontosabb azonban, hogy a vizsgálatunk során nem az egyes magyarázótényezők abszolút értékei, hanem a globalizációs nyitás periódusa (1990-1995) alatt történő változásai által indukált, az elvándorlási arányban később bekövetkezett változásokat elemeztük három időtávon: 1995 és 2000, 1995 és 2005, illetve 1995 és 2010 között. További fontos különbség, hogy a kutatásunk során nem a vándorlási egyenleg változására kerestünk magyarázatot, hanem az elvándorolt (születés szerinti) migránsállománynak az adott össznépességhez viszonyitott arányában bekövetkező változásaira. 
Kiindulópontunk szerint tehát a globális elvándorlási szintek emelkedése a kilencvenes évek második felében és azt követően, a kumulatív és modernizációs folyamatok mellett a világrendszer-elméletből ismert összefüggések valamilyen együttesének tudható be. Várakozásaink szerint e tényezők hatásai időben eltolódva jelentkeznek, ugyanakkor az idő előrehaladtával fokozatosan gyengülnek. A magyarázóváltozók körét a fent már bemutatott három, részben egymással vitatkozó, részben egymást kiegészítő paradigma alapján választottuk ki, hogy megfigyelhessük ezek magyarázóerejét, illetve hogy megvizsgáljuk, milyen öszszevont modellel tárhatjuk fel a történeti összefüggéseket. Az egyes tényezők közötti átfedés problémáját úgy is próbáltuk megoldani, hogy melyik elméleti megközelítés az, amely a legteljesebben tudja értelmezni, magához kapcsolni a „közös” tényezőket. Az elemzés során sok változóval kísérleteztünk, ezek egy részét - pl. munkanélküliség, polgárháborús konfliktusok jelenléte, foglalkoztatottsági arány stb. - a végső modellezésnél elvetettük. ${ }^{5}$

Az egyes modellekben használt változókkal kapcsolatos tudnivalókat az alábbiakban foglaltuk össze:

a) Magyarázott változók:

Az egyes országok népességének arányában kifejezett elvándorlási ráta változásai 1995 és 2000, 1995 és 2005, illetve 1995 és 2010 között. A változó számításához felhasznált adatok forrása az ENSZ Gazdasági és Szociális Ügyek Főosztálya (UN DESA) által közölt vándorlási, illetve népesedési

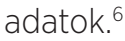

b) Magyarázóváltozók:

1) Az egyes országok népességének arányában kifejezett elvándorlási ráta változása a referencia-időszakban, 1990 és 1995 között: e magyarázóváltozó használatának kettős a célja. Egyrészt proxyváltozóként használjuk a kumulatív okság vizsgálatához, másrészt a kihagyott/nem megfigyelt változók okozta torzítások legalább részleges kezelését hivatott szolgálni. A kumulatív okságra vonatkozó hipotézisünk szerint ez a változó pozitív hatást fejt ki a későbbi elvándorlási növekményre nézve mindhárom vizsgált időtávon. A számításhoz felhasznált adatok forrása az ENSZ Gazdasági és Szociális Ügyek Főosztálya (UN DESA) által közölt vándorlási, illetve népesedési adatok.?

\footnotetext{
${ }^{5}$ Legtöbbjük esetében nem találtunk szisztematikus összefüggéseket, és/vagy magas multikollinearitást tapasztaltunk. ${ }^{6}$ https://www.un.org/en/development/desa/population/publications/database/index.asp.

${ }^{7}$ Lásd 6-os lábjegyzet.
} 
2) Az egy före jutó GDP (2015-ös konstans USA dollár) világátlaghoz viszonyított arányának változása 1990 és 1995 között: a modernizációs elméletből következő hipotézisünk szerint a relatív jövedelem növekedése javítja az elvándorlási képességet, azaz pozitív hatással van a magyarázott változóra mindhárom időtávon. E hatás azonban különböző mértékben érvényesülhet a fejlettség eltérő szintjein. A számításhoz felhasznált adatok forrása az ENSZ Kereskedelmi és Fejlesztési Konferenciája (UNCTAD) által közölt adatok. ${ }^{8}$

3) Az iskolában eltöltött évek átlagos számának változása 1990 és 1995 között: a modernizációs elméletekkel összhangban, az iskolázottság és a humán tőke növekedése pozitívan hat az elvándorlásra mindhárom időtávon, azonban e hatás különböző mértékben érvényesül a fejlettség eltérő szintjein. Az adatok forrása a Wittgenstein Centre adatbázisa. ${ }^{9}$

4) A GDP arányában kifejezett külföldi működőtőke beáramlásának (flow) változása 1990 és 1995 között: a világrendszer-elmélet szempontrendszere szerint a tőke beáramlása kiváltja a gazdasági struktúraváltást, a helyi gazdasági szerkezet átalakulását és a helyi népesség növekvő bekapcsolódását a migrációs folyamatokba. E változó esetében részben a hiányzó adatok kezelése, részben az egyes értékek extrém fluktuációjának kiküszöbölése érdekében kilencéves, mozgóátlagokat számítottunk az ENSZ Kereskedelmi és Fejlesztési Konferenciája (UNCTAD) által közölt adatok felhasználásával. ${ }^{10}$

5) A GDP arányában kifejezett külföldi tőke összállományának (stock) változása 1990 és 1995 között: hasonlóan az előbbihez, várakozásaink szerint, a külföldi tőke állományának felhalmozódása hozzájárul a helyi gazdasági szerkezet átalakulásához, így közvetve a népesség elvándorlásához is. A számításhoz felhasznált adatok forrása az ENSZ Kereskedelmi és Fejlesztési Konferenciája (UNCTAD) adatbázisa."

6) A mezőgazdasági foglalkoztatottak összes foglalkoztatotton belüli arányának változása 1990 és 1995 között: a modernizációs és a világrendszer-elméletből is ismert összefüggés szerint a munkaerőpiac

\footnotetext{
${ }^{8}$ https://unctadstat.unctad.org/EN/ Olyan, az elemzésünk szempontjából kiemelten fontos országok esetében, amelyeknél az országhatárok megváltozása vagy a korábbi államalakulatok felbomlása miatt jellemzően 1990-re nem állt rendelkezésre adat, az időben legközelebbi, rendelkezésre álló információk alapján, arányosítással pótoltuk a hiányzó értékeket.

${ }^{9}$ http://dataexplorer.wittgensteincentre.org.

${ }^{10}$ https://unctadstat.unctad.org/EN/.

${ }^{11}$ https://unctadstat.unctad.org/EN/. A hiányzó értékeket az időben legközelebbi, rendelkezésre álló adatokkal vagy arányositással pótoltuk
} 
struktúraváltása és a paraszti népesség csökkenése feltételezhetően növeli a mobilitási szinteket. Az adatok az ENSZ Kereskedelmi és Fejlesztési Konferenciája (UNCTAD) adatbázisából származnak².

7) A GDP arányában kifejezett export változása 1990 és 1995 között: az export relatív súlya a globalizációs nyitás mértékét jelzi, várakozásaink szerint az export növekedése hozzájárul elvándorlás fokozódásához. Az adatok az ENSZ Kereskedelmi és Fejlesztési Konferenciája (UNCTAD) adatbázisából származnak.13

c) Egyéb magyarázóváltozók:

1) A gazdasági fejlettség szintje, azaz az egyes országok világrendszerben elfoglalt helye: mivel a modernizációs és a világrendszer-elmélet szerint az egyes tényezők hatása a fejlettség szintjétől függően alakulhat, ennek kezelésére két dummy változót alkottunk az egy före jutó GDP (2015-ös konstans USA dollár) világátlaghoz mért arányának alapján. Ezek egyike a periféria (amennyiben az adott ország egy főre jutó GDP-je 1990-ben nem érte el a világátlag 50\%-át), a másik pedig a félperiféria országait jelölte (amelyekben az egy főre jutó GDP 1990-ben a világátlag 50 és 150\%-a közé esett). ${ }^{14}$ Referenciakategóriaként a magországok szerepeltek (amelyekben az egy főre jutó GDP 1990-ben meghaladta a világátlag 150\%-át). Mind a migrációspúp-, mind a világrendszer-elmélet szerint az elvándorlás a félperiféria országaira jellemző a leginkább. Várakozásaink szerint e kategóriában érvényesülnek majd a legjobban az egyes magyarázóváltozók. A számitáshoz felhasznált adatok forrása az ENSZ Kereskedelmi és Fejlesztési Konferenciája (UNCTAD) által közölt adatok¹5.

2) A népességszám 1995-ös értéke: mivel a kibocsátó országok népességszáma befolyásolja mind a népességarányosan kifejezett magyarázott változókat, mind az egy főre számított magyarázótényezőket, szükségesnek láttuk ennek a kontrollálását.

E változók természetes alapú logaritmusértékeinek felhasználásával, többváltozós, időbeli log-lineáris regressziók segítségével mindhárom idősávra, egyenként három modellt építettünk: az egymással részben átfedésbe kerülő

\footnotetext{
${ }^{12}$ https://unctadstat.unctad.org/EN/. Az adatbázisban nem elérhető, 1990-re vonatkozó adatokat a változó értékeinek számításánál az 1991-es értékekkel pótoltuk.

${ }^{13}$ https://unctadstat.unctad.org/EN/. A hiányzó értékeket az időben legközelebbi, rendelkezésre álló adatokkal vagy arányositással pótoltuk

${ }^{14} \mathrm{E}$ felosztás részben megegyezik Böröcz skálájával, de mi a félperiféria határát nem a világátlag 200, hanem a 150\%-ában határoztuk meg (Böröcz, 2009, 75-76).

${ }^{15} \mathrm{https}$ //unctadstat.unctad.org/EN/.
} 
modernizációs és globalizációs nyitás (világrendszer-) modelleket, illetve egy összetett, minden változót tartalmazó „teljes” modellt. A kumulatív okságra vonatkozóan nem állítottunk önálló modellt, ehelyett az erre vonatkozó változónkat, az elvándorlási arány referencia-időszaki változását beépítettük a többi modellbe. Így a modernizációs és globalizációs nyitás modelljeink közös magyarázóváltozói a következők lettek: a) az elvándorlási arány változása 1990 és 1995 között; b) az egy före jutó GDP világátlaghoz mért arányának referenciaidőszaki változása; c) az 1995-ös népességszám; d) a periféria és félperiféria dummy-k. A modernizációs modellben ezeken kivül az iskolában töltött évek átlagos számának, illetve a mezőgazdaságban foglalkoztatottak arányának referencia-időszaki változását, míg a globalizációs nyitás modelljében a GDParányos működőtőke beáramlásának, felhalmozott állományának, illetve az exportnak a változásait vizsgáltuk.

Elemzésünket egy 77 országból álló mintán végeztük el, amely sajátos demográfiai és gazdasági jellegzetességeik miatt nem tartalmazta:

- a másfél millió főnél kisebb népességgel rendelkező országokat (Khonje, 2015),

- a világ legszegényebb államait¹6, amelyek esetében a tömeges elvándorlás éppen a népesség szegénységénél fogva korlátozott, illetve a külföldi tőkebefektetések is korlátozottak (de Haas, 2010a; Solimano-Watts, 2005),

- illetve azon országokat, ahol a nagyon gyors népességnövekedés tulajdonképpen eltüntethette az elvándorolt állományok növekedését. Ez utóbbinál kihagytuk a mintából azokat az államokat, ahol az adott időszakban a népességnövekedés a megfigyelt ráta eloszlásának a legfelső 30\%-ába került.

Az országok alapadatait függelékben közöljük. Fontos megjegyeznünk, hogy az ily módon képzett mintánkon belüli migrációs folyamatok a világban lezajlottakéhoz igen hasonlóan alakultak az elmúlt évtizedekben: a népességarányos elvándorlási adatok 1990-et leszámítva tulajdonképpen azonos szintet mutatnak (lásd 8. ábra). 1990-ben a mintánkat jellemző elvándorlási arány kicsit alacsonyabb, mint a világátlag.

${ }^{16}$ A mintából kivettük azokat az országokat, amelyek egy főre jutó GDP-je nem érte el 1990-ben a világátlag 10\%-át. 
8. ábra: Elvándorlási arány a kiválasztott mintában és globálisan

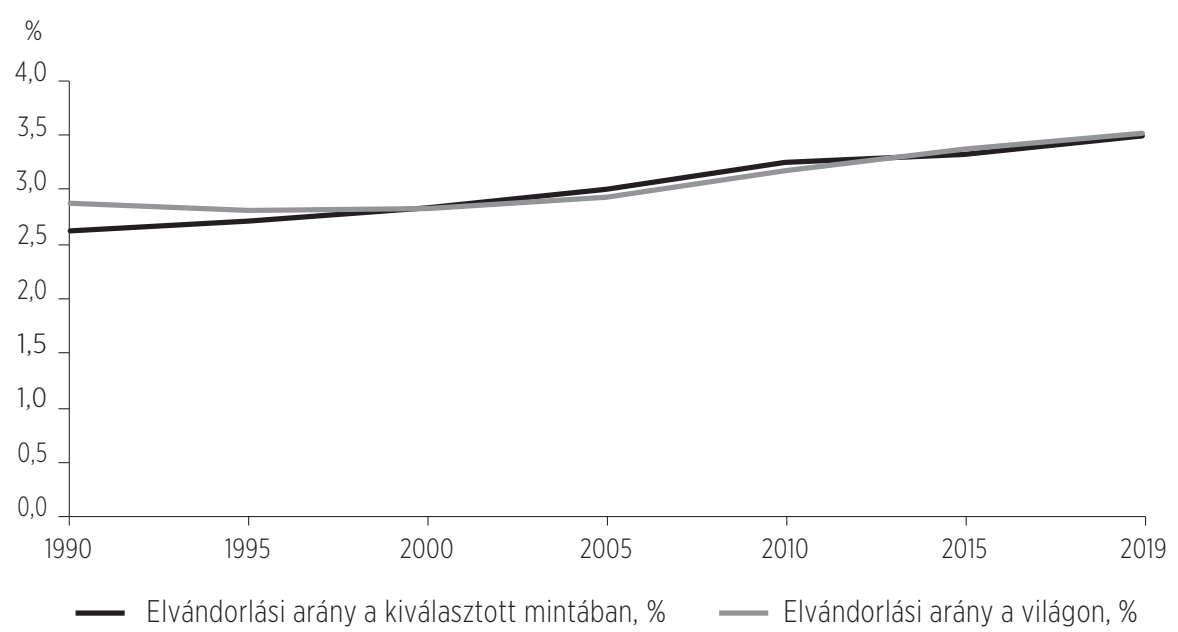

Forrás: saját ábra az ENSZ Gazdasági és Szociális Ügyek Főosztálya (UN DESA) népesedési adatbázisai (https://www.un.org/en/development/desa/population/publications/database/index.asp).

\section{EREDMÉNYEK ÉS ÉRTELMEZÉSÜK}

\subsection{EREDMÉNYEK}

Az elemzésbe bevont változók közül egy tényező mutat időszakokon és modelleken átnyúló hatást. Ez a változó a kiinduló időszaki, meg nem figyelt, a kumulatív oksággal összefüggésbe hozható népességarányos elvándorlási arányszám változása. Tehát a kiinduló időszak változásának a mértéke komoly és szignifikáns hatást gyakorolt a későbbi időszakok arányszintjeinek a változására. A legerősebb hatást a világrendszeres és az összevont modell esetében figyelhetjük meg. Minden esetben az összevonthoz képest a világrendszeres modell integrálja a legjobban ezt a változót, miközben közép- és hosszú távon a modernizációs modellen belül ez a változó elveszíti a szignifikanciáját, azaz egyre inkább véletlenszerűvé válik az összefüggés. 
1. táblázat: A népességarányos elvándorlási rátát magyarázó log-lineáris regressziók együtthatói a vizsgált időszakokban a modernizációs, a világrendszer- és az összevont modellek esetében*

\begin{tabular}{|c|c|c|c|}
\hline \multirow{3}{*}{$\begin{array}{l}\text { Népességarányos elvándorlási ráta } \\
\text { változása } 1990 \text { és } 1995 \text { között (In) }\end{array}$} & \multicolumn{3}{|c|}{$1995-2000$} \\
\hline & \multicolumn{3}{|c|}{ modernizációs, világrendszer-, összevont modell } \\
\hline & $\begin{array}{r}0,21196 \\
(0,57832) \\
{[0,03521]}\end{array}$ & $\begin{array}{r}0,51028 \\
(0,89551) \\
{[0,02983]}\end{array}$ & $\begin{array}{r}0,50655^{c} \\
(0,88897) \\
{[0,03151]}\end{array}$ \\
\hline $\begin{array}{l}\text { Egy főre jutó GDP világátlaghoz } \\
\text { viszonyított arányának változása } \\
1990 \text { és } 1995 \text { között (In) }\end{array}$ & $\begin{array}{r}0,06089 \\
(0,15712) \\
{[0,04126]}\end{array}$ & $\begin{array}{l}0,06908^{b} \\
(0,17911) \\
{[0,02629]}\end{array}$ & $\begin{array}{r}0,06917^{b} \\
(0,17935) \\
{[0,02647]}\end{array}$ \\
\hline $\begin{array}{l}\text { Iskolában eltöltött évek átlagos } \\
\text { Számának változása } 1990 \text { és } 1995 \\
\text { között (In) }\end{array}$ & $\begin{array}{r}-0,41627^{a} \\
(-0,18072) \\
{[0,22432]}\end{array}$ & & $\begin{array}{r}-0,0606 \\
(-0,02566) \\
{[0,15517]}\end{array}$ \\
\hline \multirow{2}{*}{$\begin{array}{l}\text { A mezőgazdasági foglalkoztatottak } \\
\text { összes foglalkoztatotton belüli } \\
\text { arányának változása } 1990 \text { és } 1995 \\
\text { között (In) }\end{array}$} & $\begin{array}{c}0,03193 \\
(0,0439)\end{array}$ & $\begin{array}{r}0,00355 \\
(0,00488)\end{array}$ & $\begin{array}{r}0,00382 \\
(0,00524)\end{array}$ \\
\hline & {$[0,07422]$} & {$[0,04015]$} & {$[0,04043]$} \\
\hline $\begin{array}{l}\text { GDP arányában kifejezett külföldi } \\
\text { müködőtőke beáramlásának } \\
\text { változása } 1990 \text { és } 1995 \text { között (In) }\end{array}$ & & $\begin{array}{r}0,0217 \\
(0,17637) \\
{[0,00693]}\end{array}$ & $\begin{array}{r}0,0212 \\
(0,17226) \\
{[0,00709]}\end{array}$ \\
\hline $\begin{array}{l}\text { GDP arányában kifejezett külföldi tőke } \\
\text { összállományának változása } 1990 \\
\text { és } 1995 \text { között (In) }\end{array}$ & & $\begin{array}{r}0,00051 \\
(0,01498) \\
{[0,00196]}\end{array}$ & $\begin{array}{r}0,00036755 \\
(0,01083) \\
{[0,002]}\end{array}$ \\
\hline $\begin{array}{l}\text { GDP arányában kifejezett } \\
\text { exportváltozás } 1990 \text { és } 1995 \text { között } \\
\text { (In) }\end{array}$ & & $\begin{array}{r}-0,00744 \\
(-0,02788) \\
{[0,01634]}\end{array}$ & $\begin{array}{r}-0,00852 \\
(-0,03192) \\
{[0,01668]}\end{array}$ \\
\hline Népesség 1995-ben (In) & $\begin{array}{r}0,00525 \\
(0,06749) \\
{[0,00798]}\end{array}$ & $\begin{array}{r}0,00312 \\
(0,03975) \\
{[0,00416]}\end{array}$ & $\begin{array}{r}0,00329 \\
(0,04188) \\
{[0,00421]}\end{array}$ \\
\hline Periféria & & $\begin{array}{r}0,00288 \\
(0,01307) \\
{[0,01419]}\end{array}$ & $\begin{array}{r}0,00727 \\
(0,03294) \\
{[0,01817]}\end{array}$ \\
\hline Félperiféria & & $\begin{array}{r}0,00321 \\
(0,01469) \\
{[0,01341]}\end{array}$ & $\begin{array}{r}0,00518 \\
(0,02369) \\
{[0,01441]}\end{array}$ \\
\hline Konstans & $\begin{array}{l}-0,00065 \\
{[0,13363]}\end{array}$ & $\begin{array}{r}-0,0361 \\
{[0,07072]}\end{array}$ & $\begin{array}{l}-0,03564 \\
{[0,07121]}\end{array}$ \\
\hline Korrigált R² & 0,3126 & 0,8236 & 0,8213 \\
\hline
\end{tabular}


1. táblázat: A népességarányos elvándorlási rátát magyarázó log-lineáris regressziók együtthatói a vizsgált időszakokban a modernizációs, a világrendszer-és az összevont modellek esetében* (folytatás)

\begin{tabular}{|c|c|c|c|}
\hline \multirow{3}{*}{$\begin{array}{l}\text { Népességarányos elvándorlási räta } \\
\text { változása } 1990 \text { és } 1995 \text { között (In) }\end{array}$} & \multicolumn{3}{|c|}{$1995-2005$} \\
\hline & \multicolumn{3}{|c|}{ modernizációs, világrendszer-, összevont modell } \\
\hline & $\begin{array}{r}-0,13616 \\
(-0,13211) \\
{[0,11699]}\end{array}$ & $\begin{array}{r}0,72743 \\
(0,57475) \\
{[0,11503]}\end{array}$ & $\begin{array}{r}0,71347 \\
(0,56371) \\
{[0,12151]}\end{array}$ \\
\hline $\begin{array}{l}\text { Egy főre jutó GDP világátlaghoz } \\
\text { viszonyított arányának változása } \\
1990 \text { és } 1995 \text { között (In) }\end{array}$ & $\begin{array}{r}0,21341 \\
(0,19583) \\
{[0,13711]}\end{array}$ & $\begin{array}{r}0,27943 c \\
(0,32621) \\
{[0,10138]}\end{array}$ & $\begin{array}{r}0,27978 \\
(0,32661) \\
{[0,10207]}\end{array}$ \\
\hline $\begin{array}{l}\text { Iskolában eltöltött évek átlagos } \\
\text { Számának változása } 1990 \text { és } 1995 \\
\text { között (In) }\end{array}$ & $\begin{array}{r}-1,09099 \\
(-0,16843) \\
{[0,74537]}\end{array}$ & & $\begin{array}{r}-0,22705 \\
(-0,04329) \\
{[0,5984]}\end{array}$ \\
\hline \multirow{2}{*}{$\begin{array}{l}\text { A mezőgazdasági foglalkoztatottak } \\
\text { összes foglalkoztatotton belüli } \\
\text { arányának változása } 1990 \text { és } 1995 \\
\text { között (In) }\end{array}$} & $\begin{array}{c}0,4436^{a} \\
(0,21688)\end{array}$ & $\begin{array}{c}0,32772^{b} \\
(0,20241)\end{array}$ & $\begin{array}{r}0,32873^{b} \\
(0,20303)\end{array}$ \\
\hline & {$[0,24663]$} & {$[0,15483]$} & {$[0,1559]$} \\
\hline $\begin{array}{l}\text { GDP arányában kifejezett külföldi } \\
\text { működőtőke beáramlásának } \\
\text { változása } 1990 \text { és } 1995 \text { között (In) }\end{array}$ & & $\begin{array}{l}0,05285^{a} \\
(0,19337) \\
{[0,02671]}\end{array}$ & $\begin{array}{r}0,05095^{a} \\
(0,18644) \\
{[0,02735]}\end{array}$ \\
\hline $\begin{array}{l}\text { GDP arányában kifejezett külföldi tőke } \\
\text { összállományának változása } 1990 \\
\text { és } 1995 \text { között (In) }\end{array}$ & & $\begin{array}{r}0,00686 \\
(0,09097) \\
{[0,00755]}\end{array}$ & $\begin{array}{r}0,00633 \\
(0,08397) \\
{[0,00772]}\end{array}$ \\
\hline $\begin{array}{l}\text { GDP arányában kifejezett } \\
\text { exportváltozás } 1990 \text { és } 1995 \text { között } \\
\text { (In) }\end{array}$ & & $\begin{array}{r}-0,02303 \\
(-0,03887) \\
{[0,06301]}\end{array}$ & $\begin{array}{r}-0,02707 \\
(-0,04568) \\
{[0,06432]}\end{array}$ \\
\hline Népesség 1995-ben (In) & $\begin{array}{r}0,00808 \\
(0,03692) \\
{[0,02651]}\end{array}$ & $\begin{array}{r}0,00249 \\
(0,01428) \\
{[0,01606]}\end{array}$ & $\begin{array}{r}0,00312 \\
(0,01788) \\
{[0,01625]}\end{array}$ \\
\hline Periféria & & $\begin{array}{r}0,07667 \\
(0,15648) \\
{[0,05473]}\end{array}$ & $\begin{array}{r}0,0931 \\
(0,19) \\
{[0,07007]}\end{array}$ \\
\hline Félperiféria & & $\begin{array}{c}0,10561^{\mathrm{b}} \\
(0,21755) \\
{[0,05172]}\end{array}$ & $\begin{array}{c}0,11298^{b} \\
(0,23273) \\
{[0,05557]}\end{array}$ \\
\hline Konstans & $\begin{array}{r}0,15129 \\
{[0,44404]}\end{array}$ & $\begin{array}{l}-0,00335 \\
{[0,27272]}\end{array}$ & $\begin{array}{r}-0,00164 \\
{[0,2746]}\end{array}$ \\
\hline Korrigált $\mathrm{R}^{2}$ & 0,0403 & 0,4685 & 0,4613 \\
\hline
\end{tabular}


1. táblázat: A népességarányos elvándorlási rátát magyarázó log-lineáris regressziók együtthatói a vizsgált időszakokban a modernizációs, a világrendszer- és az összevont modellek esetében* (folytatás)

\begin{tabular}{|c|c|c|c|}
\hline \multirow{3}{*}{$\begin{array}{l}\text { Népességarányos elvándorlási ráta } \\
\text { változása } 1990 \text { és } 1995 \text { között (In) }\end{array}$} & \multicolumn{3}{|c|}{$1995-2010$} \\
\hline & \multicolumn{3}{|c|}{ modernizációs, világrendszer-, összevont modell } \\
\hline & $\begin{array}{l}-0,17902 \\
(-0,1308) \\
{[0,15469]}\end{array}$ & $\begin{array}{r}0,81845^{c} \\
(0,4679) \\
{[0,16617]}\end{array}$ & $\begin{array}{r}0,79511^{c} \\
(0,45456) \\
{[0,17547]}\end{array}$ \\
\hline $\begin{array}{l}\text { Egy főre jutó GDP világátlaghoz } \\
\text { viszonyított arányának változása } \\
1990 \text { és } 1995 \text { között (In) }\end{array}$ & $\begin{array}{l}0,34518^{a} \\
(0,23852) \\
{[0,18129]}\end{array}$ & $\begin{array}{l}0,42308^{c} \\
(0,35737) \\
{[0,14645]}\end{array}$ & $\begin{array}{r}0,42366 c \\
(0,35786) \\
{[0,14738]}\end{array}$ \\
\hline $\begin{array}{l}\text { Iskolában eltöltött évek átlagos } \\
\text { Számának változása } 1990 \text { és } 1995 \\
\text { között (In) }\end{array}$ & $\begin{array}{r}-1,12121 \\
(-0,13034) \\
{[0,98556]}\end{array}$ & & $\begin{array}{r}-0,3796 \\
(-0,05237) \\
{[0,8641]}\end{array}$ \\
\hline \multirow{2}{*}{$\begin{array}{l}\text { A mezőgazdasági foglalkoztatottak } \\
\text { összes foglalkoztatotton belüli } \\
\text { arányának változása } 1990 \text { és } 1995 \\
\text { között (In) }\end{array}$} & $\begin{array}{r}0,6545^{b} \\
(0,24097)\end{array}$ & $\begin{array}{r}0,43945^{a} \\
(0,19639)\end{array}$ & $\begin{array}{c}0,44113^{a} \\
(0,19714)\end{array}$ \\
\hline & {$[0,3261]$} & {$[0,22367]$} & {$[0,22512]$} \\
\hline $\begin{array}{l}\text { GDP arányában kifejezett külföldi } \\
\text { müködőtőke beáramlásának } \\
\text { változása } 1990 \text { és } 1995 \text { között (In) }\end{array}$ & & $\begin{array}{r}0,0669^{a} \\
(0,1771) \\
{[0,03858]}\end{array}$ & $\begin{array}{r}0,06373 \\
(0,16871) \\
{[0,03949]}\end{array}$ \\
\hline $\begin{array}{l}\text { GDP arányában kifejezett külföldi tőke } \\
\text { összállományának változása } 1990 \\
\text { és } 1995 \text { között (In) }\end{array}$ & & $\begin{array}{r}0,01285 \\
(0,12331) \\
{[0,0109]}\end{array}$ & $\begin{array}{r}0,01197 \\
(0,11484) \\
{[0,01115]}\end{array}$ \\
\hline $\begin{array}{l}\text { GDP arányában kifejezett } \\
\text { exportváltozás } 1990 \text { és } 1995 \text { között } \\
\text { (In) }\end{array}$ & & $\begin{array}{r}-0,09449 \\
(-0,11538) \\
{[0,09102]}\end{array}$ & $\begin{array}{r}-0,10124 \\
(-0,12362) \\
{[0,09288]}\end{array}$ \\
\hline Népesség 1995-ben (In) & $\begin{array}{r}0,00529 \\
(0,01822) \\
{[0,03505]}\end{array}$ & $\begin{array}{r}0,0007 \\
(0,00289) \\
{[0,0232]}\end{array}$ & $\begin{array}{r}0,00175 \\
(0,00724) \\
{[0,02347]}\end{array}$ \\
\hline Periféria & & $\begin{array}{c}0,15984^{b} \\
(0,23604) \\
{[0,07906]}\end{array}$ & $\begin{array}{r}0,1873^{a} \\
(0,2766) \\
{[0,10118]}\end{array}$ \\
\hline Félperiféria & & $\begin{array}{c}0,17216^{b} \\
(0,25662) \\
{[0,07471]}\end{array}$ & $\begin{array}{c}0,18448^{b} \\
(0,27498) \\
{[0,08025]}\end{array}$ \\
\hline Konstans & $\begin{array}{r}0,31078 \\
{[0,58712]}\end{array}$ & $\begin{array}{r}0,06716 \\
{[0,39397]}\end{array}$ & $\begin{array}{r}0,07002 \\
{[0,39653]}\end{array}$ \\
\hline Korrigált $\mathrm{R}^{2}$ & 0,0486 & 0,4193 & 0,4118 \\
\hline
\end{tabular}


Ezen eredmények azt mutatják, hogy az időben előre haladva a világrendszeres modellen belül a béta értékek alapján magasabb az „elért” változás mértéke (0,50-ról megnő 0,82-ra). A kumulatív okság (a történeti kapcsolatok ereje, a kivándorlási kultúra és a network hatás) a világrendszermodellen belül egyre inkább érvényesül, ami esetleg azzal is összefügg, hogy az időben előre haladva megnőtt a figyelembe nem vett tényezők hatása, amelyeket ez a változó magába foglal. Ha térségek szerint gondoljuk át ezt az összefüggést, akkor a modellünk azt mutatja, hogy a kumulatív hatás a kiindulási szint magassága miatt különösen nagy elvándorlási hullámot Kelet-Európában és Latin-Amerikában okozhatott, ahol az országok többségében már 1990-ben a világátlag felett volt az elvándorlási arány. Így a releváns tényezők már ezen a szinten fejthették ki a hatásukat.

A világátlaghoz viszonyított jövedelmi szint változása 1990 és 1995 között pozitív módon hatott a világrendszermodellen belül a későbbi időszakok migrációs szintjének változására rövid és hosszabb időtávokon egyaránt. Ez a kapcsolat a változások között pozitívan fennállt, és az eredmények alapján úgy tűnik, hogy a migrációs púp elmélete nem igazolható. Ami azért is érdekes, mert ezek szerint a gazdagabb államokban a relatív jövedelem javulása szintén további elvándorláshoz vezet, amit a leginkább úgy értelmezhetünk, hogy a jövedelemszintek javulása az adott világrendszeres összefüggéseken belül javította az elvándorlási képességet, illetve a relatív jövedelemszintek romlása 1990 és 1995 között (leginkább Kelet-Európában és Afrikában) visszafogta az elvándorlást. Ez az eredmény meglepő, és arra figyelmeztet minket, hogy az adott modelleken belül feltételezett kényszerhatások mellett a jövedelmi képességnek is javulnia kell ahhoz, hogy nagyobb elvándorlási hullám alakuljon ki. Külön említésre méltó, hogy a modernizációs elmélet keretein belül, ahol ez az összefüggés várható volt, a kapcsolat nem volt szignifikáns, leszámítva a 15 éves időtávot.

A modernizációs változások egyik fő indikátora az iskolában eltöltött évek átlagos száma, amely különböző szintekről elindulva és különböző mértékben, de az 1990-es évek elején a mintánk minden egyes országában javult. A várakozásokkal ellentétben ez a tényező mégsem mutat szisztematikus kapcsolatot, és az iskolázottság növekedése, ezáltal a humán tőke javulása nem vezet el a migrációs állomány népességarányos növekedéséhez az adott modellben. Sőt, meglepő módon a kapcsolat negatív előjelű és rövid távon még szignifikáns is a modernizációs elméletet szimuláló modell keretein belül. Ez azt jelenti, hogy azokban az országokban, ahol minden más tényező kontrollja mellett nőtt az iskolázottsági szint, ott rövid távon csökkent az elvándorlás. Ez azt is jelentheti, hogy a migrációban leginkább érintett fiatalok jobban el tudtak helyezkedni a hazai munkaerőpiacon, köszönhetően a hosszabb iskoláztatásnak. 
Ugyancsak meglepő eredményeket kaptunk a mezőgazdasági foglalkoztatottság hatását illetően. A kapcsolat pozitív előjelü lett, azaz amennyiben nőtt az agrárfoglalkoztatottság szintje, akkor később nőtt az elvándorlási szint is. A hatás egyre erősebb lett, miközben a szignifikanciaszintek csökkentek. A hatás kimutatható volt mind a modernizációs, mind a világrendszeres értelmezési kereten belül. Ez az összefüggés azt jelenti, hogy a globalizációs nyitás esetében, minden más változó kontrollálása mellett akkor következett nagyobb mértékủ elvándorlási hullám, ha az adott ország reagrárosodott, azaz más szektorokban nem találtak (vagy nem kerestek) munkát az ott élők. Ezt az összefüggést egy sokkhatás megjelenéseként értelmezhetjük, azaz a piaci nyitás esetében bekövetkező szerkezetváltozás hatásait, pl. a helyi ipar elvesztését az ott lakók a mezőgazdaságba való meneküléssel próbálták megoldani, ami idővel elvándorláshoz vezetett. Ez az eredmény újnak tekinthető, és mind a világrendszer-, mind a modernizációs elméletnek ellentmond, vagy azokat új megvilágításba helyezi az elvándorlás alakulása szempontjából. Valós összefüggésről beszélhetünk, ami a leginkább a volt szocialista félperiférián, illetve esetenként Latin-Amerikában következett be, ahol a globalizációs nyitás különösen sokkszerü lehetett (többek között Moldova, Tádzsikisztán, Románia, Szerbia, Ukrajna, Guatemala).

A külföldi tőke beáramlása (net inflow) GDP-arányosan szignifikáns összefüggést mutat, és az eredmények, különösen rövid távon nagymértékben megfelelnek a világrendszeres várakozásoknak. A külföldi tőke növekvő beáramlása más hatások kizárásával gyengén, de szisztematikus módon növelte az elvándorlási szinteket. Így a Saskia Sassen által feltételezett makroszintủ hatásmechanizmus újabb megerősítést nyert, és állíthatjuk, hogy a külföldi tőke szerepének a növekedése a globalizáció korában szignifikáns szerepet játszott a migrációs szintek későbbi emelkedésében. A hatás rövid távon a legerősebb, és ez a Sanderson és Kentor által megállapított időbeli csúszást némileg lerövidítette, hiszen a mi módszertanunk és a változóink esetében nemcsak tíz-, hanem már ötéves időtávban is érvényesült a világrendszeres összefüggés. Ez az összefüggés a világ minden térségében szerepet játszhatott, különösen Kelet-Európában és a volt Szovjetunió területén, illetve néhány délkelet-ázsiai szocialista államban (mint Vietnám, Kambodzsa és bizonyos mértékig Kína), ahol a külföldi tőke beáramlásának a súlya messze a világátlagot meghaladóan nőtt a kiinduló időszakban. Utóbbi tekintetében Afrika, Dél-Ázsia és Nyugat-Európa esetében voltak a legalacsonyabbak ezen értékek, pontosabban ezek a térségek álttak a legközelebb a világátlaghoz. E változó esetében is érvényesültek a szisztematikus társadalmi összefüggések, amelyek a félperiféria kategóriáival írhatóak le. 
A külföldi tőke összállományának alakulása, szemben Sanderson és Kentor eredményeivel nem mutat összefüggést az elvándorlási szintek változásával. Tehát nem a külföldi tőkeállomány felhalmozódása és térnyerése, hanem a kezdeti időszakban lezajló beáramlása vezetett el a migrációs szintek növekedéséhez egy későbbi időszakban. Ugyanígy nem találtunk összefüggést az export részarányának változásával, ami igen fontos indikátora a globalizációs nyitásnak. Sőt, érdekes módon a nem szisztematikus kapcsolat negatív előjelü, azaz a kereskedelmi nyitás mintha az elvándorlást helyettesítené.

Az egyéb magyarázóváltozók közül a népességszám semmilyen kapcsolatot nem mutat, azaz önmagában nem idéz elő migrációsszint-változást. A periféria dummy változó (az egy főre jutó GDP a világátlag 10-49\%-a) csak hosszabb távon mutat pozitív összefüggést az elvándorlási szintek változásával, míg a félperiféria (egy före jutó GDP a világátlag 50-149\%-a) már tízéves időtávban is pozitív kapcsolatban van az elvándorlás alakulásával. Feltehető, hogy a fenti összefüggések a félperiféria esetében a legerősebbek, ami megfelel a világrendszeres megközelítés elvárásainak és a fenti eredményeknek.

A magyarázóerő tekintetében a modelljeink közül a világrendszeres modell és az összevont modell a legerősebb (a korrigált $R^{2}$ az 1995-2000 közötti időszakra 0,8236 és 0,8213, az 1995 és 2005 közöttire pedig 0,4685 és 0,4613). A modernizációs modell ugyanakkor rosszabbul teljesít (ugyanezen értékek 0,3126 és 0,0403). Az összevont modell magyarázóereje nem javult az iskolázottság bevonásával. A különböző elméletek közös tényezői esetében is azt láthatjuk, hogy a világrendszeres keretben érvényesülnek a leginkább, és ez olyan rendszerszintü összefüggéseket sejtet, amelyek a globalizációs nyitást tematizáló világrendszeres elméletek erejét mutatja az 1990-es és a 2000-es évek során lezajlott folyamatok esetében.

\subsection{DISZKUSSZIÓ}

\section{A modernizációs magyarázat gyengeségei}

Elemzésünk alapján úgy tünik, hogy a modernizációs tényezőkben bekövetkezett változások a kumulatív tényezővel és mezőgazdasági foglalkoztatottsággal együtt sem magyarázzák a migrációs szintek emelkedését. Sőt, több olyan kapcsolat, mint például az iskolai végzettség alakulása vagy az agrárfoglalkoztatottság nem a várt irányban fejtette ki a hatását. Ez arra int minket, hogy a kézenfekvőnek tűnő modernizációs összefüggéseket felülvizsgáljuk, és újból átgondoljuk. 
A migrációs átmenet elméletei leginkább a relatív jövedelem és a migrációs képesség változása közötti összefüggésre koncentrálnak, amennyiben az elvándorlást próbálják magyarázni. Természetesen ezzel nem vetjük el teljes egészében a modernizációs elméleteket, hiszen azok a mobilitási szintek emelkedését, és a mobilitási minták megváltozását feltételezték, tehát az elvándorlás mellett figyelembe vették a bevándorlást, a migráció összetételét és a ritmusát is. Jelen elemzésünk ez utóbbi összefüggéseket nem tárgyalja, ezen elméleti perspektíva végleges elvetéséhez további vizsgálatok szükségesek.

\section{Globalizációs nyitás és a világrendszeres modell újragondolása}

Az 1990-es évek elején a gazdasági nyitás és a felpörgő külföldi tőkebefektetések szisztematikus elvándorlásiszint-emelkedést eredményeztek rövid távon, de még 10-15 éves időbeli csúszással is. Ez a hatás csak abban az esetben érhető tetten, ha a migrációs szintek „útfüggőségét”, azaz a kiinduló elvándorlási arányok változását is figyelembe vesszük. Tehát az adott kumulatív hatások mellett a gazdasági jövedelmek relatív javulása, a mezőgazdasági foglalkoztatottság arányának növekedése, és a külföldi tőke GDP-hez mért növekvő beáramlása közösen emelik a népességarányos elvándorlási szinteket. Ezt azt jelenti, hogy bizonyos térségekben a kényszerelemek a hangsúlyosak. Pl. Kelet-Európában, a volt Szovjetunióban, Afrikában és Latin-Amerika több országában a nyitást jövedelemcsökkenés követte. Más térségekben (Nyugat-Európa, Dél- és DélkeletÁzsia) a globalizációs hatásmechanizmus nem csak kényszerelemeket tartalmaz - nem csupán lökés volt -, de a relatív gazdagodás is segítette a mobilitási szintek emelkedését. Ez egy új elem a világrendszer-elméleten alapuló gondolkodásban, ami arra hívja fel a figyelmet, hogy az elvándorlási hatás összefügg a migrációs képesség alakulásával is, amely egyszerre lehet a relatív jólét növekedése és/vagy a bevándorlást akadályozó intézkedések leépülése a célországokban. Ez utóbbi migrációs nyitás regionálisan és az országok közötti kapcsolatok szintjén is nagyon eltérő lehet, miközben tudjuk, hogy globálisan nem nőtt a nyitottság a bevándorláspolitikában (de Haas et al., 2016). Megjegyzendő azonban, hogy a külföldi tőkebeáramlás mobilizáló hatása akkor is megmarad, ha a modellből kivesszük a relatív gazdasági pozíció javulását, azaz a migrációs képességek ilyetén javulását. Másképpen megfogalmazva: itt egymást kiegészítő tényezőkről van szó.

Fontos azt is megjegyeznünk, hogy a külföldi tőke állományának a pozitív beáramlás következtében való referencia-időszaki felhalmozódása az adott 
modellben nem mutatott szisztematikus hatást. Így igazából globalizációs hatásról és az annak következtében bekövetkező átalakulási sokkról beszélhetünk csak a később meginduló migrációs hullámok kapcsán, és a külföldi tőke állományának növekedése nem jár elvándorlási hatásokkal, önmagában nem szabályozza a migrációt.

Mint azt már jeleztük, a mezőgazdasági foglalkoztatottság igen érdekes, hiszen pozitív összefüggést mutat a migrációs szintekkel. Tehát a kumulatív hatásokkal együtt a globalizációs nyitás úgy emeli meg a migrációs szinteket, hogy abban a reagrárosodás is szerepet játszik. Olyan országokban számíthatunk az elvándorlás szintjének jelentősebb emelkedésére (e tényező együtthatója igen magas), ahol a globalizációs nyitás közben a mezőgazdaságban foglalkoztatottak aránya megnőtt. Erre az összefüggésre kiváló példa Románia, Ukrajna és Moldávia, ahol a piaci nyitás következtében bedőlt a korábbi ipar egy jelentős része, és a felszabaduló munkaerő számára a mezőgazdaság volt az egyik menekülési lehetőség míg az elvándorlás volt a másik (Horváth-Kiss, 2015). Romániában az 1990-es évek elején tapasztalható visszaagrárosodás például azt jelentette, hogy a mezőgazdasági foglalkoztatottság szintje 30-ról 40\%-ra emelkedett, miközben az elvándorlási arány növekedése több mint 100\%-os volt (4,26-ról 9,85\%-ra) 1995 és 2005 között. Hasonló folyamatokat figyelhettünk meg Tádzsikisztánban, Kambodzsában és Venezuelában is.

Mindez módosítja a világrendszeres modellt, mivel a visszaagrárosodás jár együtt a migráció emelkedésével, nem pedig a mezőgazdasági foglalkoztatottság folyamatos leépülése, mint azt korábban feltételezték. Tehát a befektetési nyitás és a helyi gazdaság átalakulása az 1990-es évek elején akkor növelte meg a migrációt, ha az adott népesség nem talált utat viszonylag gyorsan a szolgáltatói szektorba. Amennyiben ez utóbbi megtörtént, akkor a hatás jóval kisebbnek bizonyult. Jó példa erre Kína, ahol a mezőgazdasági foglalkoztatottság 1990 és 1995 között 60-ról 52\%-ra esett vissza, miközben az elvándorlás 0,41-ról csak 0,55\%-ra emelkedett 1995 és 2005 között, viszont az országon belüli belső vándorlás felerősödött.

Joggal vethető fel, hogy a globalizációs nyitást értelmező modell leginkább a hierarchikus világgazdaság bizonyos strukturális helyein érvényesülhet, és azon belül is leginkább a félperiféria olyan gazdaságainál, ahol egyrészt jelentős a tőke beáramlása, másrészt komoly gazdasági szerkezeti átalakulást idéz elő a nyitás, harmadrészt külső és belső egyenlőtlenségekkel küszködik, ami így a népesség elvándorlásával járhat együtt (Böröcz, 2014). Ugyanis a mobilizálási hatások mellett még a gazdagabb országokkal szembeni bérhátrány is érvényesül, amely egyenlőtlenség visszaigazolja a vándorok egyéni és családi 
szintủ kalkulációját, miközben - szemben a nagyon szegény államokkal - már van elegendő jövedelem a migrációs költségek fedezésére. Ez különösen jellemző volt pl. a kelet-európai térségben, ahol a jóval gazdagabb Európai Unióhoz való csatlakozás érdekében komoly intézményi átalakulás kezdődött meg, miközben az unión belüli egyenlötlenségek nem változtak (Melegh, 2013b; Böröcz, 2014). Ez a feltételezés egybevág a migrációs púp elméletével is, e szerint a középső jövedelemkategóriában lévő országokban az elvándorlási ráta megugrik a többi jövedelemkategóriához képest (de Haas, 2010a). Úgy tűnik azonban, hogy önmagában csak a jövedelmi tényező nem elégséges ehhez, és ez az összefüggés csak akkor érvényesül, ha kiegészül a globalizációs nyitás világrendszeres tényezőivel: összességében éppen ezért vált kivándorló térséggé a kelet-európai és latin-amerikai félperiféria.

\section{ZÁRÓ MEGJEGYZÉSEK}

Elemzésünk azt igazolja, hogy a globalizációs nyitásra épülő történetistrukturális modell biztosítja a legjobb magyarázatot arra, hogy az 1990-es évek elejének radikális társadalmi és gazdasági változásai milyen elvándorlási hatást eredményeztek. Számításaink alapján a 2000-es években világszerte meginduló vándorlási hullám az egyenlőtlen gazdasági fejlődés miatt már fennálló migrációs folyamatokat még intenzívebbé tette, és a migráció kumulatív történeti öszszefüggései még erősebbé váltak. A globalizációs nyitással, illetve a külföldi tőke beáramlásával együttesen olyan körülmények és strukturális feltételek jöttek létre, amelyek különösen a félperiféria bizonyos területein némi időbeli csúszással jelentősen megnövelték az elvándorlást.

De az 1990-es évek első felében lezajlott történelmi vihar önmagában nem elégséges magyarázat. Egyrészt olyan „megszorulás”-nak kellett bekövetkeznie, amely nem engedte meg, hogy a globalizációs folyamatok miatt a helyi társadalmi viszonyaikban és a korábbi gazdálkodási reflexeikben megingatott emberek más szektorokba és más gazdasági terekbe tudjanak átmenekülni, hanem az agrárszféra nyújtott időszakos menedéket. Ezt a történeti modellt ki kell egészítenünk olyan elemekkel is, amelyek a migrációs képesség javulását mutatják. Önmagában a globalizációs sokk és átalakulás nem elégséges magyarázat, a tényleges fejlődési pályákat a további tényezők együttes konstellációja döntötte el.

A globalizációs nyitás így egy nagyon komplex és ellentmondásos folyamatot indított el, amelynek során bizonyos fejlődési pályákon, bizonyos strukturális 
helyzetekben a migráció emelkedése fontos szerepet játszott. Valószínủleg azon térségekben, ahol az elvándorlás növekedése más migrációs folyamatokkal is összekapcsolódott (tehát komolyabb bevándorlás történt, esetleg menekülthullám érte el az adott térséget, vagy új migrációs kapcsolatok jelentek meg), és a globalizációs nyitás más bizonytalanságai erőseknek bizonyultak, ott ez az átalakulás komolyabb politikai következményekkel is járhatott. Hiszen mára a komolyabb elvándorlással küszködő térségekben, mint például Kelet-Európában a migráció elsődleges kérdéssé nőtte ki magát. Úgy tűnik, hogy bizonyos térségekben, ahol a sokk, valamint a történelmi változás erősebb volt, a migráció mostanra már megjeleníti és megtestesíti a globalizációs átalakulás feszültségeit. Feltételezhető, hogy e politikai változás is szerepet játszik az 1980-as években megindult globalizációs ciklus történetében, talán a lezárultában majd az egyik tényező lesz. Ez a folyamat a külföldi tőkebefektetések stagnáló és csökkenő arányával mintha már el is indult volna. 


\section{IRODALOM}

Block, F. (2001). Introduction in Polanyi, K: The Great Transformation. Boston, Beacon Press. pp. XVIII-XXXVIII.

Böröcz, J. (2014). Regimes of Remittance Dependency: Global Structures and Trajectories of the Former Soviet 'Bloc'. Demográfia English Edition, 57(5), 5-37.

Böröcz J. (2018). Az EU és a világ. Kritikai elemzés. Kalligram, Budapest.

Chase-Dunn, Ch., Kawano, Y., Brewer, B. (1999). "Economic globalization since 1795: Structures and cycles in the modern world-system." Accessed December 31, 2002. Elérhető: http://wsarch.ucr.edu/archive/papers/c-d\&hall/isa99b/isa99b.htm. (2020. január 7.)

Chase-Dunn, Ch., Kawano, Y.; Brewer, B. (2000). Trade globalization since 1795: Waves of integration in the world-system. American Sociological Review, 65(1) 77-95. Published: February 2000.

Collier, P. (2013). Exodus. How Migration is Changing Our World. Oxford University Press, Oxford, New York.

Czaika, M. and de Haas, H. (2015). The Globalization of Migration: Has the World Become More Migratory? International Migration Review, 48(2) 283-323.

de Haas, H. (2010a). Migration transitions. A theoretical and empirical inquiry into the developmental drivers of international migration. DEMIG project paper, 1. International Migration Institute (IMI), Oxford Department of International Development, Queen Elizabeth House (QEH), University of Oxford.

de Haas, H. (2010b). Migration and Development: A Theoretical Perspectivel International Migration Review, 44(1) (Spring 2010), 227-264.

de Haas, H. (2011). The determinants of international migration. Conceptualizing policy, origin and destination effects. DEMIG project paper, 2. International Migration Institute (IMI), Oxford Department of International Development, Queen Elizabeth House (QEH), University of Oxford.

de Haas, H., Natter, K., Vezzoli, S. (2016). Growing Restrictiveness or Changing Selection? The Nature and Evolution of Migration Policies. International Migration Review. (Fall):1-44.

Demény, P. and McNicoll, G. (2006). World Population 1950-2000: Perception and Response. Population and Development Review, 32, The Political Economy of Global Population Change, 1950-2050 (2006), pp. 1-51. www.jstor.org/ stable/20058943. Accessed: 02-05-2018 11:55 UTC.

Faini, R. and Venturini, A. (2008). Development and migration: Lessons from Southern Europe. CHILD (CHILD - Centre for Household, Income, Labour and Demographic economics - ITALY) Working Papers (10.) http://www.child.carloalberto.org/images/ wp/child10_2008.pdf, accesed 05/01/21.

Fassmann, H., Musil, E., Bauer, R., Melegh, A., Gruber, K. (2014). Longer-Term Demographic Dynamics in South-East Europe: Convergent, Divergent and Delayed Development Paths. Central and Eastern European Migration Review, 3(2), 150-172. 
Ghosh (1963). Malthus on Emigration and Colonization: Letters to Wilmot-HortonAuthor(s): R. N. GhoshReviewed work(s): Source: Economica, New Series, 30(117) (Feb., 1963), pp. 45-62. Published by: Wiley on behalf of The London School of Economics and Political Science and The Suntory and Toyota International Centres for Economics and Related DisciplinesStable URL: http://www.jstor.org/stable/2601711 .Accessed: 26/01/2013 08:35.

Hárs, Á. (2018). Növekvő elvándorlás - lehetőségek, remények, munkaerőpiaci hatások. In Kolosi T. és Tóth, I. Gy., (szerk.), Társadalmi riport 2018 (81- 105. o.) Budapest: TÁRKI.

Harvey, D. (2005). A Brief History of Neoliberalism, Oxford: Oxford University Press.

Khonje, W. H. (ed.) (2015). Migration and Development. Perspectives from Small States. Commonwealth Secretariat, London.

Klute, G., and Hahn, H. P. (2007) Cultures of Migration: Introduction. In: H.P. Hahn and G. Klute, (Eds) Cultures of Migration. African Perspectives. Lit Verlag, Berlin.

Massey, D. S. (1999). Why does immigration occur? A theoretical synthesis. In Ch. Hirschman, Ph. Kasinitz, J. DeWind, (Eds.): The Handbook of International Migration: The American Experience. Russel Sage Foundation, New York, 34-52.

Massey, D. S., Arango, J., Hugo, G., Kouaouci, A., Pellegrino, A.,Taylor, E. J. (1998). Worlds in Motion: Understanding International Migration at the End of the Millennium. Clarendon Press, Oxford.

Melegh, A. (2013a). Net migration and historical development in Southeastern Europe since 1950. Hungarian Historical Review, 1(3-4), 144-182.

Melegh, A. (2013b). Diverging historical development of migration in Southeastern Europe since 1950. Working Papers on Population, Family and Welfare (17). Budapest: Demographic Research Institute, Hungarian Central Statistical Office.

Melegh, A., Thornton, A., Philipov, D., Young-DeMarco, L. (2013). Perceptions of societal developmental hierarchies in Europe and beyond: A Bulgarian Perspective, European Sociological Review, forthcoming Impact factor: 1.023, 5-Yr impact factor: 1.873. 2013 Jun 1; 29(3):603-615.

Melegh A. és Sárosi A. (2015). Magyarország bekapcsolódása a migrációs folyamatokba: történeti-strukturális megközelítés. Demográfia, 58 (4): 221-265. doi: 10.21543./ dem.58.4.1.

Melegh, A., Kiss, T., Csánoová, S., Young-DeMarco, L., Thornton, A. (2016). The perception of global hierarchies: South Eastern European patterns in comparative perspectives. In Chinese Journal of Sociology. 2016, 2(4), 497-523.

Portes, A. and Böröcz, J. (1989). Contemporary Immigration: Theoretical Perspectives on Its Determinants and Modes of Incorporation. International Migration Review, 23(3), 606-630.

Portes, A. (ed.) 1995. The Economic Sociology of Immigration. Essays on Networks, Ethnicity, and Entrepreneurship. Russel Sage Foundation, New York.

Salmenhaara, P. Social capital in the mobilization of human capital. Demográfia, 2009, English Edition. 52(5), pp. 97-123.

Sanderson, M. R. and Kentor, J. (2008). Foreign Direct Investment and International Migration A Cross-National Analysis of Less-Developed Countries, 1985-2000. International Sociology, July 2008, 23(4), 514-539. 
Sassen, S. [1988] 2006: Foreign investment: a neglected variable. In A. M. Messina, G. Lahav, (Eds.): The Migration Reader. Exploring Politics and Policies. Lynne Rienner Publishers, London, 596-608.

Sen, A. (1999): Development as freedom. New York: Oxford University Press.

Sík E. (2011a). A migrációs burok jövője a globális-transznacionális világban. In Sík E. (szerk): A migráció szociológiája. 2. köt. ELTE TáTK, Budapest 133-158. https://regi. tankonyvtar.hu/hu/tartalom/tamop425/0010_2A_15_Sik_Endre_Migracio_szociologiaja_2_Valogatta_es_szerk_Sik_Endre/ch09.html

Skoglund, E. and Csányi, Z. (2019). Quantitative analysis of the objective and subjective aspects of youth migration in the Danube region. YOUMIG Working Papers no.3. Leibniz Institute for East and Southeast European Studies.

Solimano, A. and Watts, N. (2005). International migration, capital flows and the global economy: a long run view. Economic Development Division, United Nations Publications, Santiago, Chile 2005.

Stalker, P. (2000). Workers Without Frontiers: The Impact of Globalization on International Migration. London and Boulder, CO: Lynne Rienner, 2000. Pp.xii + 163.

Thornton, A. "International Family Change and Continuity: the Past and Future from the Developmental Idealism Perspective." In E. Scott and M. Garrison, (Eds.). Marriage at the Crossroads: Legal, Social, and Policy Perspectives. Cambridge: Cambridge University Press, 2012.

Xiang, B., Lindquist, J. (2014). Migration Infrastructure. International Migration Review, 48 (1), 122-148

Wilson, C. (2001). On the Scale of Global Demographic Convergence 1950-2000. Population and Development Review, 27(1), pp. 155-171.

Zelinsky, W. (1971). The Hypothesis of the Mobility Transition. Geographical Review, 61(2) (Apr.,1971), pp. 219-249. 


\section{OPENING-UP TO GLOBAL MARKETS AND RISING LEVELS OF MIGRATION: STEPS TOWARDS A GLOBAL AND HISTORICAL UNDERSTANDING OF HOW THE CURRENT GLOBALIZATION CYCLE BEGAN}

\section{ABSTRACT}

Our analysis concerns how opening-up to global markets, and consequent societal changes, affected the levels of outmigration as well as of its patterns around the world. We performed log-linear regressions on a global sample of 77 countries in order to draw conclusions on how - resulting from different aspects of socio-economic change between 1990 and 1995 - emigration rates changed in later time periods. In doing so, cumulative causation, modernization and world-system theories were utilized. In addition to models linked to these paradigms, emigration processes were also examined through a joint model of all considered variables. A dual approach to temporality is a specific feature of our research. On the one hand, we were less interested in the immediate, cross-sectional migratory effects of each determinants, instead, based on previous research, we hypothesized that such effects appear later in time. Thus, our analysis was carried out using time lags of five, ten and fifteen years. On the other hand, unlike previous research, not the absolute values of variables, but their change in different time intervals have been taken into account. Our results suggest that a quite surprising combination of the factors of cumulative mechanisms (path dependence of migration), of modernization processes (increasing migration capability) and of the world-systems analysis were decisive. While the effects of determinants might change over time, it is world-systems analysis, modified in some aspects, that provides the most appropriate framework for integrating them. 


\section{MELLÉKLET}

1. függelék

A mintában szereplő országok népessége

(fö)

\begin{tabular}{|c|c|c|c|c|c|}
\hline & 1990 & 1995 & 2000 & 2005 & 2010 \\
\hline Albánia & 3286070 & 3112923 & 3129246 & 3086810 & 2948029 \\
\hline Algéria & 25758872 & 28757788 & 31042238 & 33149720 & 35977451 \\
\hline Amerikai Egyesült Államok & 252120309 & 265163741 & 281710914 & 294993509 & 309011469 \\
\hline Argentína & 32618648 & 34828168 & 36870796 & 38892924 & 40895751 \\
\hline Ausztrália & 16960600 & 17993083 & 18991434 & 20178543 & 22154687 \\
\hline Ausztria & 7723954 & 7990113 & 8069276 & 8253656 & 8409945 \\
\hline Belgium & 10006545 & 10186304 & 10282046 & 10546885 & 10938735 \\
\hline Bolívia & 6864839 & 7622334 & 8418270 & 9232301 & 10048597 \\
\hline Brazília & 149003225 & 162019889 & 174790339 & 186127108 & 195713637 \\
\hline Bulgária & 8841466 & 8379305 & 7997951 & 7686964 & 7425011 \\
\hline Chile & 13274617 & 14380864 & 15342350 & 16182713 & 17062531 \\
\hline Costa Rica & 3119436 & 3545524 & 3962369 & 4285504 & 4577371 \\
\hline Cseh Köztársaság & 10340877 & 10358190 & 10289374 & 10258165 & 10536514 \\
\hline Dánia & 5141117 & 5232709 & 5341192 & 5421701 & 5554849 \\
\hline Dél-afrikai Köztársaság & 36800507 & 41435761 & 44967713 & 47880595 & 51216967 \\
\hline Dominikai Köztársaság & 7133491 & 7819239 & 8471317 & 9097262 & 9695117 \\
\hline Ecuador & 10230931 & 11455205 & 12681123 & 13825839 & 15011114 \\
\hline Egyesült Királyság & 57134377 & 57932450 & 58923305 & 60287953 & 63459801 \\
\hline \multicolumn{6}{|l|}{ Egyiptomi Arab } \\
\hline Köztársaság & 56134478 & 62334025 & 68831561 & 75523576 & 82761244 \\
\hline Észak-Macedónia & 1996218 & 1983259 & 2034823 & 2060280 & 2070737 \\
\hline Észtország & 1565246 & 1433026 & 1399111 & 1355650 & 1332103 \\
\hline Fehéroroszország & 10151135 & 10077606 & 9871635 & 9562083 & 9420576 \\
\hline Finnország & 4996220 & 5119012 & 5187953 & 5258933 & 5365784 \\
\hline Franciaország & 56666861 & 57801887 & 59015092 & 61120128 & 62879535 \\
\hline Fülöp-szigetek & 61895169 & 69784087 & 77991757 & 86326251 & 93966784 \\
\hline Görögország & 10225990 & 10745502 & 11082103 & 11224800 & 10887640 \\
\hline Grúzia & 5410400 & 4976252 & 4362184 & 4210158 & 4099096 \\
\hline Haiti & 7037915 & 7744509 & 8463802 & 9195289 & 9949318 \\
\hline Hollandia & 14965442 & 15467852 & 15926188 & 16367153 & 16682927 \\
\hline Horvátország & 4776370 & 4616763 & 4428075 & 4378066 & 4328163 \\
\hline Iráni Iszlám Köztársaság & 56366212 & 61442658 & 65623397 & 69762345 & 73762519 \\
\hline Írország & 3510881 & 3592180 & 3783095 & 4141218 & 4554330 \\
\hline Jamaica & 2419901 & 2533705 & 2654698 & 2740000 & 2810464 \\
\hline Japán & 124505243 & 126365486 & 127524168 & 128326115 & 128542349 \\
\hline Kanada & 27541323 & 29164153 & 30588379 & 32164313 & 34147566 \\
\hline Kazahsztán & 16383881 & 15839357 & 14922724 & 15402803 & 16252273 \\
\hline Kína & 1176883681 & 1240920539 & 1290550767 & 1330776380 & 1368810604 \\
\hline
\end{tabular}

Forrás: az ENSZ Gazdasági és Szociális Ügyek Főosztálya (UN DESA) népesedési adatbázis (https://www.un.org/en/ development/desa/population/publications/database/index.asp). 
A mintában szereplő országok népessége (folytatás)

(fő)

\begin{tabular}{|c|c|c|c|c|c|}
\hline & 1990 & 1995 & 2000 & 2005 & 2010 \\
\hline Kirgizisztán & 4372885 & 4566096 & 4920712 & 5075340 & 5422298 \\
\hline Kolumbia & 33102569 & 36421438 & 39629965 & 42647731 & 45222699 \\
\hline Koreai Köztársaság & 42918416 & 45292521 & 47379237 & 48701069 & 49545638 \\
\hline $\begin{array}{l}\text { Koreai Népi Demokratikus } \\
\text { Köztársaság }\end{array}$ & 20293057 & 21862300 & 22929078 & 23904167 & 24548840 \\
\hline Lengyelország & 37960193 & 38458642 & 38556699 & 38368957 & 38329784 \\
\hline Lettország & 2664447 & 2508476 & 2384150 & 2251996 & 2118855 \\
\hline Litvánia & 3696035 & 3626609 & 3501842 & 3344259 & 3123825 \\
\hline Magyarország & 10377135 & 10349308 & 10220509 & 10085942 & 9927380 \\
\hline Marokkó & 24807461 & 26994255 & 28793672 & 30455563 & 32343384 \\
\hline Mexikó & 83943135 & 91663290 & 98899845 & 106005199 & 114092961 \\
\hline Moldovai Köztársaság & 4365562 & 4340602 & 4202659 & 4159296 & 4086090 \\
\hline Mongólia & 2184139 & 2298017 & 2397417 & 2526429 & 2719902 \\
\hline Németország & 79053984 & 81138653 & 81400883 & 81602739 & 80827001 \\
\hline Nicaragua & 4173435 & 4652185 & 5069310 & 5438692 & 5824058 \\
\hline Norvégia & 4247286 & 4366996 & 4499375 & 4632359 & 4885878 \\
\hline Olaszország & 57048237 & 57174412 & 56692178 & 58281209 & 59325232 \\
\hline Oroszország & 147531562 & 148227471 & 146404890 & 143672125 & 143479273 \\
\hline Örményország & 3538164 & 3217349 & 3069597 & 2981262 & 2877314 \\
\hline Panamai Köztársaság & 2470946 & 2739667 & 3030333 & 3330222 & 3642691 \\
\hline Paraguayi Köztársaság & 4223413 & 4776838 & 5323202 & 5824095 & 6248017 \\
\hline Peru & 22071433 & 24299168 & 26459944 & 27866140 & 29027680 \\
\hline Portugália & 9895358 & 10091322 & 10297117 & 10508494 & 10596055 \\
\hline Románia & 23489156 & 22964747 & 22137423 & 21417287 & 20471860 \\
\hline Salvador & 5270074 & 5628602 & 5887930 & 6052124 & 6183877 \\
\hline Sierra Leone & 4319763 & 4303953 & 4584570 & 5645629 & 6415636 \\
\hline Spanyolország & 39202524 & 39787413 & 40824745 & 44019118 & 46931011 \\
\hline Sri Lanka & 17325769 & 18242917 & 18777606 & 19544988 & 20261738 \\
\hline Svédország & 8567375 & 8836421 & 8881642 & 9038627 & 9390157 \\
\hline Szlovák Köztársaság & 5288455 & 5375470 & 5399207 & 5398962 & 5404293 \\
\hline Szlovénia & 2006404 & 1991126 & 1987710 & 1994979 & 2043336 \\
\hline Tádzsikisztán & 5283811 & 5764806 & 6216329 & 6789318 & 7527397 \\
\hline Thaiföld & 56558196 & 59467272 & 62952639 & 65416189 & 67195032 \\
\hline Törökország & 53921758 & 58486453 & 63240196 & 67903461 & 72326992 \\
\hline Tunézia & 8242509 & 9125400 & 9708347 & 10106778 & 10635245 \\
\hline Türkmenisztán & 3683978 & 4207841 & 4516128 & 4754652 & 5087211 \\
\hline Új-Zéland & 3398175 & 3674940 & 3858992 & 4135353 & 4370060 \\
\hline Ukrajna & 51463101 & 50903783 & 48838058 & 46890775 & 45792086 \\
\hline Uruguay & 3109598 & 3224275 & 3319734 & 3321799 & 3359273 \\
\hline Venezuela & 19632665 & 21931087 & 24192449 & 26432445 & 28439942 \\
\hline Zimbabwe & 10432409 & 11410721 & 11881482 & 12076697 & 12697728 \\
\hline
\end{tabular}

Forrás: az ENSZ Gazdasági és Szociális Ügyek Föosztálya (UN DESA) népesedési adatbázis (https://www.un.org/en/ development/desa/population/publications/database/index.asp). 
2. függelék

A mintában szereplő országokból elvándorolt népességállomány

(fö)

\begin{tabular}{|c|c|c|c|c|c|}
\hline & 1990 & 1995 & 2000 & 2005 & 2010 \\
\hline Albánia & 180284 & 501142 & 824413 & 966234 & 1120305 \\
\hline Algéria & 921727 & 979704 & 1038048 & 1599882 & 1656453 \\
\hline Amerikai Egyesült Államok & 1739233 & 1839745 & 1991803 & 2291218 & 2669958 \\
\hline Argentína & 430169 & 481996 & 555587 & 808409 & 938087 \\
\hline Ausztrália & 303696 & 344311 & 385120 & 430599 & 487844 \\
\hline Ausztria & 506088 & 490849 & 478831 & 494587 & 520152 \\
\hline Belgium & 365360 & 376028 & 400064 & 439693 & 487203 \\
\hline Bolívia & 224693 & 283540 & 344713 & 543783 & 780095 \\
\hline Brazília & 500392 & 751469 & 970453 & 1220052 & 1518343 \\
\hline Bulgária & 613093 & 649577 & 688832 & 906520 & 1106684 \\
\hline Chile & 493026 & 499207 & 512014 & 542211 & 570644 \\
\hline Costa Rica & 69711 & 85421 & 105682 & 118673 & 133027 \\
\hline Cseh Köztársaság & 277260 & 333356 & 400971 & 607009 & 782250 \\
\hline Dánia & 201761 & 207983 & 218071 & 225671 & 234437 \\
\hline Dél-afrikai Köztársaság & 308303 & 386225 & 501905 & 602433 & 745100 \\
\hline Dominikai Köztársaság & 466216 & 675282 & 897785 & 1023442 & 1185546 \\
\hline Ecuador & 214008 & 326230 & 446391 & 987059 & 1152628 \\
\hline Egyesült Királyság & 3794333 & 3713904 & 3866248 & 4148316 & 4450254 \\
\hline \multicolumn{6}{|l|}{ Egyiptomi Arab } \\
\hline Köztársaság & 1322178 & 1492244 & 1708513 & 1901661 & 2611870 \\
\hline Észak-Macedónia & 432296 & 492304 & 532531 & 459289 & 527075 \\
\hline Észtország & 113905 & 129640 & 141883 & 150427 & 160489 \\
\hline Fehéroroszország & 1767606 & 1736499 & 1685652 & 1581211 & 1465141 \\
\hline Finnország & 250765 & 288821 & 316039 & 302908 & 290411 \\
\hline Franciaország & 1215895 & 1353418 & 1555610 & 1725773 & 1957969 \\
\hline Fülöp-szigetek & 2033684 & 2508005 & 3092284 & 3712857 & 4719359 \\
\hline Görögország & 1022459 & 1004521 & 983006 & 868029 & 792872 \\
\hline Grúzia & 919454 & 953289 & 967024 & 888613 & 813454 \\
\hline Haiti & 528873 & 665028 & 805430 & 972717 & 1123759 \\
\hline Hollandia & 723638 & 734149 & 755052 & 799588 & 866675 \\
\hline Horvátország & 425807 & 735556 & 907454 & 840203 & 822331 \\
\hline Iráni Iszlám Köztársaság & 631339 & 746894 & 831372 & 889941 & 989560 \\
\hline İrország & 917286 & 863749 & 820902 & 771302 & 730771 \\
\hline Jamaica & 589010 & 719398 & 858815 & 906462 & 989512 \\
\hline Japán & 608921 & 657199 & 712768 & 722116 & 760479 \\
\hline Kanada & 998163 & 1069031 & 1148499 & 1190001 & 1272338 \\
\hline Kazahsztán & 2971639 & 3295163 & 3554491 & 3718750 & 3803375 \\
\hline Kína & 4231648 & 5030369 & 5885006 & 7327438 & 8733242 \\
\hline
\end{tabular}

Forrás: az ENSZ Gazdasági és Szociális Ügyek Főosztálya (UN DESA) népesedési adatbázis (https://www.un.org/en/ development/desa/population/publications/database/index.asp). 
A mintában szereplő országokból elvándorolt népességállomány (folytatás)

(fő)

\begin{tabular}{|c|c|c|c|c|c|}
\hline & 1990 & 1995 & 2000 & 2005 & 2010 \\
\hline Kirgizisztán & 522578 & 550026 & 566319 & 652862 & 726917 \\
\hline Kolumbia & 1009935 & 1217608 & 1436444 & 1887924 & 2526525 \\
\hline Koreai Köztársaság & 1624729 & 1785743 & 1952161 & 2039728 & 2309955 \\
\hline $\begin{array}{l}\text { Koreai Népi Demokratikus } \\
\text { Köztársaság }\end{array}$ & 39784 & 54029 & 72414 & 86930 & 96575 \\
\hline Lengyelország & 1510415 & 1776628 & 2048371 & 2887741 & 3731041 \\
\hline Lettország & 215134 & 229015 & 238691 & 271170 & 279368 \\
\hline Litvánia & 341050 & 342455 & 348620 & 412612 & 519665 \\
\hline Magyarország & 387514 & 404699 & 421411 & 468156 & 513838 \\
\hline Marokkó & 1748251 & 1884066 & 2077160 & 2473209 & 2863810 \\
\hline Mexikó & 4395365 & 6949297 & 9562929 & 10818079 & 12414825 \\
\hline Moldovai Köztársaság & 625683 & 620036 & 602782 & 715599 & 827763 \\
\hline Mongólia & 24466 & 27694 & 30649 & 42378 & 57766 \\
\hline Németország & 2929448 & 3045354 & 3235354 & 3446260 & 3727333 \\
\hline Nicaragua & 442126 & 438387 & 502243 & 436780 & 610902 \\
\hline Norvégia & 138536 & 151368 & 164243 & 175298 & 181698 \\
\hline Olaszország & 3351006 & 3207777 & 3067571 & 2699529 & 2563339 \\
\hline Oroszország & 12662893 & 11621262 & 10721414 & 10358533 & 10130259 \\
\hline Örményország & 899649 & 901872 & 876470 & 898086 & 917350 \\
\hline Panamai Köztársaság & 134743 & 133405 & 137430 & 132266 & 140609 \\
\hline Paraguayi Köztársaság & 297979 & 336064 & 374876 & 545839 & 766008 \\
\hline Peru & 314854 & 509283 & 699598 & 973644 & 1302167 \\
\hline Portugália & 1873457 & 1922320 & 1995386 & 1744741 & 1950392 \\
\hline Románia & 813066 & 977495 & 1139475 & 2108741 & 3370044 \\
\hline Salvador & 1242075 & 933330 & 949270 & 1119319 & 1337458 \\
\hline Sierra Leone & 61854 & 457828 & 509099 & 147931 & 126868 \\
\hline Spanyolország & 1439019 & 1362439 & 1290279 & 1113967 & 1086552 \\
\hline Sri Lanka & 885951 & 925755 & 981294 & 1137286 & 1410887 \\
\hline Svédország & 206848 & 226803 & 258000 & 270865 & 304911 \\
\hline Szlovák Köztársaság & 133006 & 191650 & 251584 & 272294 & 261356 \\
\hline Szlovénia & 91496 & 108668 & 118724 & 119620 & 123291 \\
\hline Tádzsikisztán & 537701 & 555428 & 541185 & 586243 & 584770 \\
\hline Thaiföld & 311308 & 417273 & 537198 & 637455 & 773556 \\
\hline Törökország & 2640033 & 2771722 & 2891893 & 2749962 & 2723385 \\
\hline Tunézia & 465576 & 476954 & 486980 & 579219 & 616386 \\
\hline Türkmenisztán & 259987 & 243524 & 223704 & 229249 & 236614 \\
\hline Új-Zéland & 388173 & 417098 & 490020 & 556056 & 662996 \\
\hline Ukrajna & 5545760 & 5606432 & 5596883 & 5567629 & 5433315 \\
\hline Uruguay & 237486 & 233993 & 235641 & 299038 & 338334 \\
\hline Venezuela & 185946 & 242811 & 319240 & 438692 & 558491 \\
\hline Zimbabwe & 204365 & 288001 & 351996 & 499882 & 715395 \\
\hline
\end{tabular}

Forrás: az ENSZ Gazdasági és Szociális Ügyek Főosztálya (UN DESA) népesedési adatbázis (https://www.un.org/en/ development/desa/population/publications/database/index.asp). 
3. függelék

A mintában szereplő országok népességének arányában kifejezett elvándorlási ráta

$(\%)$

\begin{tabular}{|c|c|c|c|c|c|}
\hline & 1990 & 1995 & 2000 & 2005 & 2010 \\
\hline Albánia & 5,49 & 16,10 & 26,35 & 31,30 & 38,00 \\
\hline Algéria & 3,58 & 3,41 & 3,34 & 4,83 & 4,60 \\
\hline Amerikai Egyesült Államok & 0,69 & 0,69 & 0,71 & 0,78 & 0,86 \\
\hline Argentína & 1,32 & 1,38 & 1,51 & 2,08 & 2,29 \\
\hline Ausztrália & 1,79 & 1,91 & 2,03 & 2,13 & 2,20 \\
\hline Ausztria & 6,55 & 6,14 & 5,93 & 5,99 & 6,18 \\
\hline Belgium & 3,65 & 3,69 & 3,89 & 4,17 & 4,45 \\
\hline Bolívia & 3,27 & 3,72 & 4,09 & 5,89 & 7,76 \\
\hline Brazília & 0,34 & 0,46 & 0,56 & 0,66 & 0,78 \\
\hline Bulgária & 6,93 & 7,75 & 8,61 & 11,79 & 14,90 \\
\hline Chile & 3,71 & 3,47 & 3,34 & 3,35 & 3,34 \\
\hline Costa Rica & 2,23 & 2,41 & 2,67 & 2,77 & 2,91 \\
\hline Cseh Köztársaság & 2,68 & 3,22 & 3,90 & 5,92 & 7,42 \\
\hline Dánia & 3,92 & 3,97 & 4,08 & 4,16 & 4,22 \\
\hline Dél-afrikai Köztársaság & 0,84 & 0,93 & 1,12 & 1,26 & 1,45 \\
\hline Dominikai Köztársaság & 6,54 & 8,64 & 10,60 & 11,25 & 12,23 \\
\hline Ecuador & 2,09 & 2,85 & 3,52 & 7,14 & 7,68 \\
\hline Egyesült Királyság & 6,64 & 6,41 & 6,56 & 6,88 & 7,01 \\
\hline \multicolumn{6}{|l|}{ Egyiptomi Arab } \\
\hline Köztársaság & 2,36 & 2,39 & 2,48 & 2,52 & 3,16 \\
\hline Észak-Macedónia & 21,66 & 24,82 & 26,17 & 22,29 & 25,45 \\
\hline Észtország & 7,28 & 9,05 & 10,14 & 11,10 & 12,05 \\
\hline Fehéroroszország & 17,41 & 17,23 & 17,08 & 16,54 & 15,55 \\
\hline Finnország & 5,02 & 5,64 & 6,09 & 5,76 & 5,41 \\
\hline Franciaország & 2,15 & 2,34 & 2,64 & 2,82 & 3,11 \\
\hline Fülöp-szigetek & 3,29 & 3,59 & 3,96 & 4,30 & 5,02 \\
\hline Görögország & 10,00 & 9,35 & 8,87 & 7,73 & 7,28 \\
\hline Grúzia & 16,99 & 19,16 & 22,17 & 21,11 & 19,84 \\
\hline Haiti & 7,51 & 8,59 & 9,52 & 10,58 & 11,29 \\
\hline Hollandia & 4,84 & 4,75 & 4,74 & 4,89 & 5,19 \\
\hline Horvátország & 8,91 & 15,93 & 20,49 & 19,19 & 19,00 \\
\hline Iráni Iszlám Köztársaság & 1,12 & 1,22 & 1,27 & 1,28 & 1,34 \\
\hline İrország & 26,13 & 24,05 & 21,70 & 18,63 & 16,05 \\
\hline Jamaica & 24,34 & 28,39 & 32,35 & 33,08 & 35,21 \\
\hline Japán & 0,49 & 0,52 & 0,56 & 0,56 & 0,59 \\
\hline Kanada & 3,62 & 3,67 & 3,75 & 3,70 & 3,73 \\
\hline Kazahsztán & 18,14 & 20,80 & 23,82 & 24,14 & 23,40 \\
\hline Kína & 0,36 & 0,41 & 0,46 & 0,55 & 0,64 \\
\hline
\end{tabular}

Forrás: az ENSZ Gazdasági és Szociális Ügyek Főosztálya (UN DESA) népesedési adatbázis (https://www.un.org/en/ development/desa/population/publications/database/index.asp). 
A mintában szereplő országok népességének arányában kifejezett elvándorlási ráta (folytatás)

(\%)

\begin{tabular}{|c|c|c|c|c|c|}
\hline & 1990 & 1995 & 2000 & 2005 & 2010 \\
\hline Kirgizisztán & 11,95 & 12,05 & 11,51 & 12,86 & 13,41 \\
\hline Kolumbia & 3,05 & 3,34 & 3,62 & 4,43 & 5,59 \\
\hline Koreai Köztársaság & 3,79 & 3,94 & 4,12 & 4,19 & 4,66 \\
\hline Koreai Népi Demokratikus & & & & & \\
\hline Köztársaság & 0,20 & 0,25 & 0,32 & 0,36 & 0,39 \\
\hline Lengyelország & 3,98 & 4,62 & 5,31 & 7,53 & 9,73 \\
\hline Lettország & 8,07 & 9,13 & 10,01 & 12,04 & 13,18 \\
\hline Litvánia & 9,23 & 9,44 & 9,96 & 12,34 & 16,64 \\
\hline Magyarország & 3,73 & 3,91 & 4,12 & 4,64 & 5,18 \\
\hline Marokkó & 7,05 & 6,98 & 7,21 & 8,12 & 8,85 \\
\hline Mexikó & 5,24 & 7,58 & 9,67 & 10,21 & 10,88 \\
\hline Moldovai Köztársaság & 14,33 & 14,28 & 14,34 & 17,20 & 20,26 \\
\hline Mongólia & 1,12 & 1,21 & 1,28 & 1,68 & 2,12 \\
\hline Németország & 3,71 & 3,75 & 3,97 & 4,22 & 4,61 \\
\hline Nicaragua & 10,59 & 9,42 & 9,91 & 8,03 & 10,49 \\
\hline Norvégia & 3,26 & 3,47 & 3,65 & 3,78 & 3,72 \\
\hline Olaszország & 5,87 & 5,61 & 5,41 & 4,63 & 4,32 \\
\hline Oroszország & 8,58 & 7,84 & 7,32 & 7,21 & 7,06 \\
\hline Örményország & 25,43 & 28,03 & 28,55 & 30,12 & 31,88 \\
\hline Panamai Köztársaság & 5,45 & 4,87 & 4,54 & 3,97 & 3,86 \\
\hline Paraguayi Köztársaság & 7,06 & 7,04 & 7,04 & 9,37 & 12,26 \\
\hline Peru & 1,43 & 2,10 & 2,64 & 3,49 & 4,49 \\
\hline Portugália & 18,93 & 19,05 & 19,38 & 16,60 & 18,41 \\
\hline Románia & 3,46 & 4,26 & 5,15 & 9,85 & 16,46 \\
\hline Salvador & 23,57 & 16,58 & 16,12 & 18,49 & 21,63 \\
\hline Sierra Leone & 1,43 & 10,64 & 11,10 & 2,62 & 1,98 \\
\hline Spanyolország & 3,67 & 3,42 & 3,16 & 2,53 & 2,32 \\
\hline Sri Lanka & 5,11 & 5,07 & 5,23 & 5,82 & 6,96 \\
\hline Svédország & 2,41 & 2,57 & 2,90 & 3,00 & 3,25 \\
\hline Szlovák Köztársaság & 2,52 & 3,57 & 4,66 & 5,04 & 4,84 \\
\hline Szlovénia & 4,56 & 5,46 & 5,97 & 6,00 & 6,03 \\
\hline Tádzsikisztán & 10,18 & 9,63 & 8,71 & 8,63 & 7,77 \\
\hline Thaiföld & 0,55 & 0,70 & 0,85 & 0,97 & 1,15 \\
\hline Törökország & 4,90 & 4,74 & 4,57 & 4,05 & 3,77 \\
\hline Tunézia & 5,65 & 5,23 & 5,02 & 5,73 & 5,80 \\
\hline Türkmenisztán & 7,06 & 5,79 & 4,95 & 4,82 & 4,65 \\
\hline Új-Zéland & 11,42 & 11,35 & 12,70 & 13,45 & 15,17 \\
\hline Ukrajna & 10,78 & 11,01 & 11,46 & 11,87 & 11,87 \\
\hline Uruguay & 7,64 & 7,26 & 7,10 & 9,00 & 10,07 \\
\hline Venezuela & 0,95 & 1,11 & 1,32 & 1,66 & 1,96 \\
\hline Zimbabwe & 1,96 & 2,52 & 2,96 & 4,14 & 5,63 \\
\hline
\end{tabular}

Forrás: az ENSZ Gazdasági és Szociális Ügyek Főosztálya (UN DESA) népesedési adatbázis (https://www.un.org/en/ development/desa/population/publications/database/index.asp). 
4. függelék

A mintában szereplő országok egy före jutó GDP-jének (2015-ös konstans USA dollár) világátlaghoz viszonyított aránya

(\%)

\begin{tabular}{|c|c|c|c|c|c|}
\hline & 1990 & 1995 & 2000 & 2005 & 2010 \\
\hline Albánia & 23,82 & 21,73 & 24,71 & 30,29 & 38,01 \\
\hline Algéria & 46,36 & 40,46 & 39,71 & 43,54 & 42,13 \\
\hline Amerikai Egyesült Államok & 581,33 & 603,84 & 627,75 & 618,83 & 572,09 \\
\hline Argentína & 129,06 & 154,83 & 148,51 & 140,84 & 157,58 \\
\hline Ausztrália & 493,43 & 524,20 & 537,44 & 543,81 & 526,61 \\
\hline Ausztria & 462,09 & 479,62 & 492,02 & 477,39 & 463,19 \\
\hline Belgium & 435,03 & 444,91 & 453,82 & 442,92 & 425,89 \\
\hline Bolívia & 25,88 & 27,41 & 26,28 & 25,37 & 27,04 \\
\hline Brazília & 92,94 & 95,17 & 87,14 & 85,33 & 93,57 \\
\hline Bulgária & 62,32 & 56,48 & 47,84 & 59,70 & 67,15 \\
\hline Chile & 80,85 & 108,89 & 111,86 & 120,11 & 126,98 \\
\hline Costa Rica & 88,83 & 97,82 & 96,55 & 98,04 & 107,30 \\
\hline Cseh Köztársaság & $175,43^{a}$ & 158,75 & 156,06 & 172,40 & 175,43 \\
\hline Dánia & 583,07 & 618,31 & 628,31 & 601,32 & 549,54 \\
\hline Dél-afrikai Köztársaság & 68,17 & 60,80 & 57,47 & 59,23 & 59,76 \\
\hline Dominikai Köztársaság & 38,57 & 43,62 & 50,26 & 50,61 & 59,62 \\
\hline Ecuador & 63,36 & 63,02 & 53,73 & 56,78 & 57,24 \\
\hline Egyesült Királyság & 451,78 & 469,46 & 487,10 & 497,63 & 448,93 \\
\hline Egyiptomi Arab & & & & & \\
\hline Köztársaság & 28,07 & 30,56 & 31,91 & 31,69 & 36,15 \\
\hline Észak-Macedónia & $65,14^{\mathrm{a}}$ & 41,37 & 41,73 & 41,32 & 46,31 \\
\hline Észtország & $125,55^{a}$ & 102,53 & 127,44 & 170,20 & 157,99 \\
\hline Fehéroroszország & $47,74^{a}$ & 27,21 & 33,75 & 45,46 & 60,74 \\
\hline Finnország & 463,78 & 426,08 & 482,47 & 492,41 & 468,23 \\
\hline Franciaország & 435,61 & 438,03 & 443,25 & 423,06 & 396,93 \\
\hline Fülöp-szigetek & 24,94 & 23,68 & 22,57 & 23,21 & 25,13 \\
\hline Görögország & 230,40 & 224,41 & 232,70 & 252,77 & 237,50 \\
\hline Grúzia & $25,21^{\text {a }}$ & 13,79 & 18,68 & 25,06 & 30,79 \\
\hline Haiti & 14,82 & 11,43 & 10,59 & 8,63 & 7,67 \\
\hline Hollandia & 460,96 & 480,54 & 516,14 & 488,16 & 475,19 \\
\hline Horvátország & $144,29^{a}$ & 102,20 & 112,47 & 128,97 & 124,06 \\
\hline Iráni Iszlám Köztársaság & 48,96 & 49,89 & 50,45 & 54,96 & 58,60 \\
\hline Írország & 342,15 & 403,47 & 536,42 & 577,41 & 496,93 \\
\hline Jamaica & 69,27 & 73,62 & 62,68 & 59,67 & 52,60 \\
\hline Japán & 410,88 & 419,27 & 392,40 & 376,00 & 349,49 \\
\hline Kanada & 472,80 & 467,47 & 485,31 & 476,60 & 440,44 \\
\hline Kazahsztán & $89,36^{a}$ & 52,08 & 55,91 & 80,67 & 95,74 \\
\hline Kína & 12,96 & 21,08 & 27,41 & 38,57 & 59,24 \\
\hline
\end{tabular}

a Az időben legközelebbi, rendelkezésre álló információk alapján, illetve arányosítással pótolva.

Forrás: saját számítás az ENSZ Kereskedelmi és Fejlesztési Konferencia (UNCTAD) adatbázisa (https://unctadstat. unctad.org/EN/) és az ENSZ Gazdasági és Szociális Ügyek Főosztálya (UN DESA) népesedési adatbázis alapján (https://www.un.org/en/development/desa/population/publications/database/index.asp). 
A mintában szereplő országok egy före jutó GDP-jének (2015-ös konstans USA dollár) világátlaghoz viszonyitott aránya (folytatás)

$(\%)$

\begin{tabular}{|c|c|c|c|c|c|}
\hline & 1990 & 1995 & 2000 & 2005 & 2010 \\
\hline Kirgizisztán & $17,68^{\mathrm{a}}$ & 8,37 & 9,13 & 9,69 & 10,44 \\
\hline Kolumbia & 54,18 & 58,79 & 50,57 & 51,04 & 55,48 \\
\hline Koreai Köztársaság & 141,15 & 192,74 & 215,18 & 243,35 & 273,71 \\
\hline $\begin{array}{l}\text { Koreai Népi Demokratikus } \\
\text { Köztársaság }\end{array}$ & 13,54 & 9,60 & 7,81 & 7,71 & 6,92 \\
\hline Lengyelország & 76,06 & 80,42 & 92,69 & 98,60 & 115,42 \\
\hline Lettország & $99,37^{\mathrm{a}}$ & 69,42 & 84,26 & 120,17 & 115,34 \\
\hline Litvánia & $114,52^{\mathrm{a}}$ & 70,52 & 82,03 & 112,70 & 118,33 \\
\hline Magyarország & 127,94 & 109,49 & 114,50 & 130,80 & 121,87 \\
\hline Marokkó & 22,72 & 21,04 & 21,28 & 23,32 & 27,02 \\
\hline Mexikó & 108,82 & 105,43 & 113,04 & 102,97 & 95,41 \\
\hline Moldovai Köztársaság & $27,81^{\mathrm{a}}$ & 14,58 & 11,88 & 15,36 & 16,98 \\
\hline Mongólia & 26,33 & 20,86 & 20,55 & 24,27 & 28,59 \\
\hline Németország & 438,87 & 453,70 & 443,83 & 413,46 & 410,13 \\
\hline Nicaragua & 18,66 & 17,59 & 18,44 & 18,26 & 18,05 \\
\hline Norvégia & 737,09 & 828,60 & 859,13 & 845,96 & 779,31 \\
\hline Olaszország & 406,05 & 415,17 & 414,56 & 383,75 & 344,29 \\
\hline Oroszország & $119,02^{\mathrm{a}}$ & 70,07 & 68,67 & 85,68 & 94,60 \\
\hline Örményország & $15,42^{\mathrm{a}}$ & 13,47 & 16,21 & 27,44 & 31,83 \\
\hline Panamai Köztársaság & 77,24 & 87,57 & 88,78 & 90,70 & 110,02 \\
\hline Paraguayi Köztársaság & 52,72 & 52,95 & 42,09 & 45,52 & 51,22 \\
\hline Peru & 40,05 & 45,17 & 42,15 & 44,87 & 55,66 \\
\hline Portugália & 218,07 & 223,84 & 239,62 & 222,90 & 210,96 \\
\hline Románia & 72,26 & 63,86 & 58,57 & 72,42 & 80,70 \\
\hline Salvador & 31,69 & 38,52 & 38,27 & 38,03 & 37,00 \\
\hline Sierra Leone & 11,14 & 8,33 & 4,10 & 5,51 & 5,79 \\
\hline Spanyolország & 278,97 & 284,95 & 303,49 & 300,79 & 274,17 \\
\hline Sri Lanka & 18,51 & 22,05 & 24,49 & 26,05 & 31,72 \\
\hline Svédország & 508,57 & 490,80 & 521,70 & 530,52 & 519,28 \\
\hline Szlovák Köztársaság & $117,01^{\mathrm{a}}$ & 107,30 & 113,47 & 131,85 & 154,86 \\
\hline Szlovénia & $253,15^{a}$ & 189,31 & 207,33 & 223,81 & 222,12 \\
\hline Tádzsikisztán & $16,35^{\mathrm{a}}$ & 6,68 & 5,55 & 7,33 & 8,39 \\
\hline Thaiföld & 37,28 & 51,28 & 44,90 & 51,21 & 55,52 \\
\hline Törökország & 79,16 & 82,23 & 83,10 & 88,90 & 90,70 \\
\hline Tunézia & 29,41 & 30,89 & 34,04 & 36,85 & 40,39 \\
\hline Türkmenisztán & $53,79^{a}$ & 28,39 & 29,42 & 32,58 & 46,22 \\
\hline Új-Zéland & 376,63 & 391,16 & 385,63 & 398,01 & 376,25 \\
\hline Ukrajna & $47,57^{\mathrm{a}}$ & 21,61 & 18,22 & 24,96 & 23,99 \\
\hline Uruguay & 117,48 & 133,11 & 128,70 & 118,02 & 144,44 \\
\hline Venezuela & 154,79 & 157,91 & 132,87 & 125,43 & 129,56 \\
\hline Zimbabwe & 14,01 & 13,08 & 11,12 & 7,99 & 11,94 \\
\hline
\end{tabular}

a Az időben legközelebbi, rendelkezésre álló információk alapján, illetve arányositással pótolva.

Forrás: saját számítás az ENSZ Kereskedelmi és Fejlesztési Konferencia (UNCTAD) adatbázisa (https://unctadstat. unctad.org/EN/) és az ENSZ Gazdasági és Szociális Ügyek Föosztálya (UN DESA) népesedési adatbázis alapján (https://www.un.org/en/development/desa/population/publications/database/index.asp). 
5. függelék

Az iskolában eltöltött évek átlagos száma a mintában szereplő országokban

(\%)

\begin{tabular}{|c|c|c|c|c|c|}
\hline & 1990 & 1995 & 2000 & 2005 & 2010 \\
\hline Albánia & 8,12 & 8,54 & 9,09 & 9,40 & 9,68 \\
\hline Algéria & 4,63 & 5,66 & 6,54 & 7,34 & 8,09 \\
\hline Amerikai Egyesült Államok & 11,66 & 11,90 & 12,10 & 12,25 & 12,40 \\
\hline Argentína & 7,86 & 8,26 & 8,66 & 9,06 & 9,43 \\
\hline Ausztrália & 11,26 & 11,61 & 11,97 & 12,35 & 12,72 \\
\hline Ausztria & 9,71 & 10,16 & 10,50 & 10,79 & 11,07 \\
\hline Belgium & 9,44 & 9,84 & 10,21 & 10,58 & 10,90 \\
\hline Bolívia & 5,92 & 6,43 & 6,98 & 7,58 & 8,16 \\
\hline Brazília & 5,00 & 5,45 & 5,87 & 6,32 & 6,81 \\
\hline Bulgária & 9,40 & 9,74 & 10,06 & 10,31 & 10,54 \\
\hline Chile & 8,82 & 9,33 & 9,78 & 10,19 & 10,57 \\
\hline Costa Rica & 7,05 & 7,42 & 7,74 & 8,06 & 8,42 \\
\hline Cseh Köztársaság & 11,25 & 11,46 & 11,66 & 11,88 & 12,10 \\
\hline Dánia & 11,24 & 11,46 & 11,66 & 11,84 & 11,98 \\
\hline Dél-afrikai Köztársaság & 6,88 & 7,49 & 8,11 & 8,61 & 9,08 \\
\hline Dominikai Köztársaság & 5,22 & 5,82 & 6,35 & 6,89 & 7,47 \\
\hline Ecuador & 6,21 & 6,85 & 7,38 & 7,83 & 8,28 \\
\hline Egyesült Királyság & 11,55 & 11,79 & 12,02 & 12,25 & 12,49 \\
\hline $\begin{array}{l}\text { Egyiptomi Arab } \\
\text { Köztársaság }\end{array}$ & 3,92 & 4,58 & 5,26 & 6,07 & 6,86 \\
\hline Észak-Macedónia & 6,45 & 7,25 & 7,90 & 8,49 & 9,08 \\
\hline Észtország & 11,44 & 11,89 & 12,24 & 12,48 & 12,62 \\
\hline Fehéroroszország & 8,99 & 9,44 & 9,93 & 10,38 & 10,79 \\
\hline Finnország & 10,51 & 10,96 & 11,34 & 11,69 & 11,97 \\
\hline Franciaország & 9,24 & 9,67 & 10,08 & 10,46 & 10,84 \\
\hline Fülöp-szigetek & 7,34 & 7,74 & 8,08 & 8,44 & 8,78 \\
\hline Görögország & 8,04 & 8,70 & 9,29 & 9,81 & 10,30 \\
\hline Grúzia & 10,22 & 10,75 & 11,18 & 11,52 & 11,77 \\
\hline Haiti & 1,91 & 2,27 & 2,74 & 3,36 & 4,14 \\
\hline Hollandia & 10,28 & 10,63 & 10,92 & 11,17 & 11,40 \\
\hline Horvátország & 9,35 & 9,76 & 10,18 & 10,58 & 10,96 \\
\hline Iráni Iszlám Köztársaság & 4,63 & 5,37 & 6,15 & 7,01 & 7,86 \\
\hline Írország & 9,26 & 9,68 & 10,17 & 10,82 & 11,53 \\
\hline Jamaica & 7,49 & 8,15 & 8,68 & 9,10 & 9,48 \\
\hline Japán & 11,67 & 12,05 & 12,43 & 12,77 & 13,07 \\
\hline Kanada & 11,97 & 12,33 & 12,66 & 12,95 & 13,21 \\
\hline Kazahsztán & 9,17 & 9,51 & 9,87 & 10,23 & 10,67 \\
\hline Kína & 5,49 & 6,11 & 6,62 & 7,02 & 7,44 \\
\hline
\end{tabular}

Forrás: Wittgenstein Centre Human Capital Data Explorer (http://dataexplorer.wittgensteincentre.org). 
Az iskolában eltöltött évek átlagos száma a mintában szereplő országokban (folytatás)

\begin{tabular}{|c|c|c|c|c|c|}
\hline & 1990 & 1995 & 2000 & 2005 & 2010 \\
\hline Kirgizisztán & 8,75 & 9,27 & 9,66 & 9,99 & 10,38 \\
\hline Kolumbia & 5,45 & 5,95 & 6,39 & 6,87 & 7,33 \\
\hline Koreai Köztársaság & 8,95 & 9,74 & 10,44 & 11,00 & 11,56 \\
\hline $\begin{array}{l}\text { Koreai Népi Demokratikus } \\
\text { Köztársaság }\end{array}$ & 9,32 & 9,83 & 10,23 & 10,49 & 10,68 \\
\hline Lengyelország & 10,89 & 11,16 & 11,43 & 11,70 & 11,96 \\
\hline Lettország & 11,42 & 11,63 & 11,82 & 11,98 & 12,10 \\
\hline Litvánia & 10,92 & 11,55 & 12,04 & 12,38 & 12,69 \\
\hline Magyarország & 9,68 & 10,16 & 10,61 & 11,04 & 11,38 \\
\hline Marokkó & 1,94 & 2,42 & 2,90 & 3,33 & 4,00 \\
\hline Mexikó & 5,71 & 6,41 & 7,02 & 7,53 & 8,01 \\
\hline Moldovai Köztársaság & 7,63 & 8,42 & 9,11 & 9,73 & 10,22 \\
\hline Mongólia & 8,11 & 8,75 & 9,21 & 9,49 & 9,80 \\
\hline Németország & 12,50 & 12,71 & 12,86 & 12,99 & 13,13 \\
\hline Nicaragua & 4,03 & 4,51 & 4,92 & 5,31 & 5,77 \\
\hline Norvégia & 11,46 & 11,66 & 11,87 & 12,09 & 12,35 \\
\hline Olaszország & 7,90 & 8,46 & 8,98 & 9,48 & 9,93 \\
\hline Oroszország & 8,23 & 8,74 & 9,23 & 9,66 & 10,05 \\
\hline Örményország & 9,58 & 9,88 & 10,19 & 10,49 & 10,75 \\
\hline Panamai Köztársaság & 7,34 & 7,88 & 8,33 & 8,72 & 9,09 \\
\hline Paraguayi Köztársaság & 5,98 & 6,44 & 6,88 & 7,34 & 7,81 \\
\hline Peru & 7,29 & 7,89 & 8,43 & 8,90 & 9,39 \\
\hline Portugália & 4,33 & 5,02 & 5,77 & 6,55 & 7,17 \\
\hline Románia & 8,92 & 9,44 & 9,87 & 10,25 & 10,57 \\
\hline Salvador & 4,46 & 5,03 & 5,57 & 6,07 & 6,61 \\
\hline Sierra Leone & 2,05 & 2,37 & 2,73 & 3,03 & 3,51 \\
\hline Spanyolország & 7,21 & 7,85 & 8,48 & 9,11 & 9,59 \\
\hline Sri Lanka & 6,79 & 7,49 & 8,24 & 8,94 & 9,60 \\
\hline Svédország & 10,22 & 10,65 & 11,02 & 11,36 & 11,69 \\
\hline Szlovák Köztársaság & 11,19 & 11,43 & 11,65 & 11,90 & 12,17 \\
\hline Szlovénia & 10,72 & 10,90 & 11,08 & 11,27 & 11,49 \\
\hline Tádzsikisztán & 9,68 & 10,43 & 10,96 & 11,32 & 11,58 \\
\hline Thaiföld & 7,80 & 8,27 & 8,63 & 9,01 & 9,40 \\
\hline Törökország & 5,41 & 6,05 & 6,67 & 7,26 & 7,82 \\
\hline Tunézia & 3,68 & 4,41 & 5,17 & 5,95 & 6,91 \\
\hline Türkmenisztán & 10,13 & 10,56 & 10,89 & 11,08 & 10,90 \\
\hline Új-Zéland & 11,21 & 11,66 & 12,05 & 12,41 & 12,71 \\
\hline Ukrajna & 8,48 & 9,09 & 9,57 & 9,99 & 10,33 \\
\hline Uruguay & 7,18 & 7,59 & 7,98 & 8,32 & 8,62 \\
\hline Venezuela & 7,39 & 7,96 & 8,43 & 8,87 & 9,30 \\
\hline Zimbabwe & 7,05 & 8,01 & 8,83 & 9,53 & 10,05 \\
\hline
\end{tabular}

Forrás: Wittgenstein Centre Human Capital Data Explorer (http://dataexplorer.wittgensteincentre.org). 
6. függelék

A mezőgazdasági foglalkoztatottak összes foglalkoztatotton belüli aránya a mintában szereplő országokban

(\%)

\begin{tabular}{|c|c|c|c|c|c|}
\hline & $1990^{a}$ & 1995 & 2000 & 2005 & 2010 \\
\hline Albánia & 55,91 & 54,26 & 51,59 & 47,21 & 42,08 \\
\hline Algéria & 23,95 & 23,53 & 22,21 & 18,43 & 11,86 \\
\hline Amerikai Egyesült Államok & 1,90 & 1,81 & 1,63 & 1,41 & 1,42 \\
\hline Argentína & 0,34 & 0,62 & 0,67 & 1,28 & 1,27 \\
\hline Ausztrália & 5,46 & 4,94 & 4,86 & 3,58 & 3,23 \\
\hline Ausztria & 7,71 & 7,34 & 6,05 & 5,27 & 5,21 \\
\hline Belgium & 2,99 & 2,68 & 1,91 & 2,04 & 1,35 \\
\hline Bolívia & 42,09 & 41,25 & 38,94 & 38,61 & 29,99 \\
\hline Brazília & 18,98 & 18,14 & 16,48 & 16,62 & 12,65 \\
\hline Bulgária & 19,54 & 16,80 & 13,20 & 8,94 & 6,82 \\
\hline Chile & 19,09 & 15,70 & 14,44 & 13,16 & 10,60 \\
\hline Costa Rica & 18,03 & 17,67 & 16,30 & 15,25 & 11,41 \\
\hline Cseh Köztársaság & 8,23 & 6,64 & 5,22 & 3,98 & 3,10 \\
\hline Dánia & 5,46 & 4,39 & 3,67 & 3,18 & 2,42 \\
\hline Dél-afrikai Köztársaság & 11,25 & 10,91 & 9,93 & 7,05 & 4,86 \\
\hline Dominikai Köztársaság & 21,74 & 20,34 & 15,60 & 13,68 & 12,42 \\
\hline Ecuador & 29,26 & 28,91 & 29,67 & 30,35 & 27,88 \\
\hline Egyesült Királyság & 2,16 & 2,05 & 1,53 & 1,38 & 1,22 \\
\hline $\begin{array}{l}\text { Egyiptomi Arab } \\
\text { Köztársasáq }\end{array}$ & 39,29 & 33,99 & 29,63 & 30,94 & 28,28 \\
\hline Észak-Macedónia & 25,79 & 25,93 & 24,34 & 20,79 & 18,61 \\
\hline Észtország & 19,25 & 10,18 & 6,36 & 5,19 & 4,22 \\
\hline Fehéroroszország & 16,41 & 16,12 & 14,84 & 12,82 & 11,03 \\
\hline Finnország & 8,89 & 7,76 & 6,21 & 4,82 & 4,44 \\
\hline Franciaország & 5,74 & 4,89 & 4,14 & 3,64 & 2,91 \\
\hline Fülöp-szigetek & 44,90 & 43,41 & 37,15 & 35,36 & 32,84 \\
\hline Görögország & 22,09 & 20,43 & 17,40 & 12,16 & 12,40 \\
\hline Grúzia & 48,62 & 48,46 & 52,17 & 54,34 & 48,09 \\
\hline Haiti & 38,79 & 38,70 & 36,82 & 35,49 & 33,56 \\
\hline Hollandia & 4,28 & 3,83 & 3,28 & 3,70 & 3,06 \\
\hline Horvátország & 22,37 & 20,64 & 16,55 & 17,30 & 14,25 \\
\hline Iráni Iszlám Köztársaság & 24,63 & 23,98 & 24,53 & 24,75 & 19,22 \\
\hline Írország n & 13,81 & 12,01 & 7,95 & 5,91 & 5,75 \\
\hline Jamaica & 28,04 & 23,20 & 20,85 & 18,10 & 17,81 \\
\hline Japán & 6,73 & 5,70 & 5,09 & 4,46 & 4,07 \\
\hline Kanada & 3,49 & 3,15 & 2,52 & 2,12 & 1,81 \\
\hline Kazahsztán & 38,68 & 38,77 & 36,60 & 32,41 & 28,28 \\
\hline Kína & 59,70 & 52,20 & 50,01 & 44,80 & 36,70 \\
\hline
\end{tabular}

a Az 1990-re vonatkozó hiányzó adatokat minden esetben az 1991-es adatokkal pótoltuk.

Forrás: az ENSZ Kereskedelmi és Fejlesztési Konferencia (UNCTAD) adatbázisa (https://unctadstat.unctad.org/EN/). 
A mezőgazdasági foglalkoztatottak összes foglalkoztatotton belüli aránya a mintában szereplő országokban (folytatás)

\begin{tabular}{|c|c|c|c|c|c|}
\hline & $1990^{\mathrm{a}}$ & 1995 & 2000 & 2005 & 2010 \\
\hline Kirgizisztán & 35,50 & 47,19 & 53,08 & 38,50 & 32,34 \\
\hline Kolumbia & 23,13 & 22,41 & 22,33 & 20,60 & 18,38 \\
\hline Koreai Köztársaság & 14,61 & 11,77 & 10,60 & 7,94 & 6,60 \\
\hline $\begin{array}{l}\text { Koreai Népi Demokratikus } \\
\text { Köztársaság }\end{array}$ & 55,52 & 56,33 & 56,31 & 54,39 & 53,53 \\
\hline Lengyelország & 25,57 & 22,63 & 18,67 & 17,38 & 13,05 \\
\hline Lettország & 18,59 & 17,53 & 14,93 & 12,05 & 8,61 \\
\hline Litvánia & 22,59 & 21,95 & 19,24 & 14,27 & 8,83 \\
\hline Magyarország & 11,77 & 8,02 & 6,46 & 4,87 & 4,54 \\
\hline Marokkó & 47,46 & 47,09 & 45,11 & 45,48 & 40,53 \\
\hline Mexikó & 25,94 & 23,48 & 17,41 & 15,03 & 13,92 \\
\hline Moldovai Köztársaság & 43,03 & 45,19 & 50,87 & 40,65 & 27,52 \\
\hline Mongólia & 43,52 & 46,14 & 48,64 & 39,88 & 33,53 \\
\hline Németország & 3,50 & 3,17 & 2,64 & 2,37 & 1,65 \\
\hline Nicaragua & 34,00 & 33,63 & 31,53 & 28,89 & 29,41 \\
\hline Norvégia & 6,06 & 5,46 & 4,29 & 3,30 & 2,55 \\
\hline Olaszország & 8,30 & 6,58 & 5,23 & 4,20 & 3,77 \\
\hline Oroszország & 14,24 & 15,77 & 14,49 & 10,14 & 7,75 \\
\hline Örményország & 44,83 & 45,41 & 43,25 & 38,28 & 38,60 \\
\hline Panamai Köztársaság & 27,30 & 20,80 & 16,97 & 15,68 & 17,42 \\
\hline Paraguayi Köztársaság & 33,78 & 32,94 & 33,31 & 32,02 & 25,62 \\
\hline Peru & 36,63 & 35,31 & 34,68 & 34,82 & 27,73 \\
\hline Portugália & 11,88 & 11,48 & 12,68 & 12,05 & 11,20 \\
\hline Románia & 29,78 & 40,33 & 45,21 & 32,29 & 31,01 \\
\hline Salvador & 28,56 & 26,77 & 21,61 & 19,99 & 20,78 \\
\hline Sierra Leone & 71,23 & 71,17 & 70,18 & 68,06 & 63,91 \\
\hline Spanyolország & 10,21 & 8,99 & 6,69 & 5,30 & 4,20 \\
\hline Sri Lanka & 42,84 & 39,57 & 41,25 & 37,27 & 31,82 \\
\hline Svédország & 3,85 & 3,49 & 2,91 & 2,32 & 2,10 \\
\hline Szlovák Köztársaság & 11,10 & 9,20 & 6,93 & 4,75 & 3,23 \\
\hline Szlovénia & 10,86 & 10,44 & 9,60 & 9,11 & 8,82 \\
\hline Tádzsikisztán & 56,10 & 60,02 & 60,24 & 55,47 & 52,43 \\
\hline Thaiföld & 60,33 & 51,97 & 48,79 & 38,68 & 38,24 \\
\hline Törökország & 47,81 & 43,39 & 39,32 & 25,68 & 23,70 \\
\hline Tunézia & 23,36 & 22,30 & 20,52 & 18,52 & 17,95 \\
\hline Türkmenisztán & 31,30 & 31,02 & 30,33 & 28,09 & 24,81 \\
\hline Új-Zéland & 10,76 & 9,67 & 8,70 & 7,16 & 6,74 \\
\hline Ukrajna & 23,92 & 25,12 & 25,14 & 22,14 & 20,33 \\
\hline Uruguay & 12,47 & 12,22 & 11,64 & 10,94 & 11,57 \\
\hline Venezuela & 12,64 & 13,52 & 10,61 & 10,28 & 8,26 \\
\hline Zimbabwe & 60,76 & 60,62 & 60,61 & 64,55 & 65,53 \\
\hline
\end{tabular}

a Az 1990-re vonatkozó hiányzó adatokat minden esetben az 1991-es adatokkal pótoltuk.

Forrás: az ENSZ Kereskedelmi és Fejlesztési Konferencia (UNCTAD) adatbázisa (https://unctadstat.unctad.org/EN/). 
7. függelék

A GDP arányában kifejezett külföldi müködőtőke beáramlása (flow) a mintában szereplő országokban

(\%)

\begin{tabular}{|c|c|c|c|c|c|}
\hline & 1990 & 1995 & 2000 & 2005 & 2010 \\
\hline Albánia & 2,19 & 2,27 & 3,92 & 5,63 & 7,56 \\
\hline Algéria & 0,03 & 0,41 & 1,10 & 1,49 & 1,28 \\
\hline Amerikai Egyesült Államok & 0,76 & 1,22 & 1,49 & 1,21 & 1,42 \\
\hline Argentína & 1,30 & 2,63 & 2,45 & 2,28 & 2,04 \\
\hline Ausztrália & 1,83 & 1,44 & 2,80 & 2,72 & 3,57 \\
\hline Ausztria & 0,49 & 0,99 & 2,16 & 2,56 & 2,10 \\
\hline Belgium & 3,42 & 8,45 & 20,64 & 12,07 & 8,68 \\
\hline Bolívia & 1,50 & 6,89 & 7,57 & 3,50 & 3,70 \\
\hline Brazília & 0,36 & 1,40 & 3,19 & 2,58 & 2,54 \\
\hline Bulgária & 0,24 & 1,57 & 8,88 & 16,58 & 9,05 \\
\hline Chile & 3,02 & 4,71 & 6,62 & 6,79 & 8,26 \\
\hline Costa Rica & 2,28 & 3,24 & 4,34 & 6,69 & 5,85 \\
\hline Cseh Köztársaság & 2,48 & 4,03 & 7,02 & 4,74 & 2,72 \\
\hline Dánia & 0,99 & 2,49 & 4,87 & 1,43 & 0,89 \\
\hline Dél-afrikai Köztársaság & 0,03 & 0,61 & 1,42 & 1,73 & 1,48 \\
\hline Dominikai Köztársaság & 1,41 & 2,60 & 3,26 & 3,89 & 4,06 \\
\hline Ecuador & 1,48 & 2,08 & 3,49 & 1,43 & 0,75 \\
\hline Egyesült Királyság & 1,59 & 2,44 & 3,14 & 3,60 & 3,31 \\
\hline $\begin{array}{l}\text { Egyiptomi Arab } \\
\text { Köztársaság }\end{array}$ & 2,59 & 1,24 & 0,98 & 5,50 & 3,04 \\
\hline Észak-Macedónia & 0,77 & 1,21 & 4,66 & 5,78 & 3,96 \\
\hline Észtország & 3,00 & 5,44 & 8,58 & 10,11 & 7,25 \\
\hline Fehéroroszország & 0,05 & 1,00 & 1,95 & 2,57 & 3,32 \\
\hline Finnország & 0,38 & 1,98 & 4,14 & 2,30 & 2,33 \\
\hline Franciaország & 0,98 & 1,48 & 1,57 & 1,18 & 1,07 \\
\hline Fülöp-szigetek & 1,55 & 1,54 & 1,50 & 1,51 & 1,26 \\
\hline Görögország & 0,91 & 0,65 & 0,74 & 0,90 & 0,86 \\
\hline Grúzia & 0,17 & 5,26 & 7,07 & 11,05 & 9,99 \\
\hline Haiti & 0,16 & 0,26 & 0,28 & 1,03 & 1,71 \\
\hline Hollandia & 1,94 & 3,52 & 7,79 & 5,21 & 3,91 \\
\hline Horvátország & 0,58 & 2,11 & 4,89 & 5,65 & 4,47 \\
\hline Iráni Iszlám Köztársaság & $-0,06$ & 0,04 & 1,01 & 1,08 & 0,61 \\
\hline Írország & 1,44 & 6,09 & 12,09 & 2,51 & 12,13 \\
\hline Jamaica & 1,89 & 3,48 & 5,14 & 6,74 & 4,80 \\
\hline Japán & 0,02 & 0,05 & 0,13 & 0,20 & 0,13 \\
\hline Kanada & 0,95 & 1,81 & 2,87 & 3,26 & 3,44 \\
\hline Kazahsztán & 2,18 & 4,90 & 10,94 & 11,40 & 7,70 \\
\hline Kína & 2,57 & 4,34 & 3,92 & 3,13 & 1,77 \\
\hline
\end{tabular}

Forrás: az ENSZ Kereskedelmi és Fejlesztési Konferencia (UNCTAD) adatbázisa (https://unctadstat.unctad.org/EN/). 
A GDP arányában kifejezett külföldi müködőtöke beáramlása (flow) a mintában szereplő országokban (folytatás)

\begin{tabular}{|c|c|c|c|c|c|}
\hline & 1990 & 1995 & 2000 & 2005 & 2010 \\
\hline Kirgizisztán & 0,94 & 4,10 & 4,15 & 5,55 & 7,77 \\
\hline Kolumbia & 1,16 & 1,79 & 2,80 & 4,13 & 3,99 \\
\hline Koreai Köztársaság & 0,38 & 0,58 & 1,28 & 1,00 & 0,86 \\
\hline $\begin{array}{l}\text { Koreai Népi Demokratikus } \\
\text { Köztársaság }\end{array}$ & 0,01 & 0,13 & 0,13 & 0,08 & 0,47 \\
\hline Lengyelország & 0,80 & 2,45 & 3,77 & 3,29 & 2,66 \\
\hline Lettország & 1,38 & 4,81 & 4,39 & 4,69 & 4,68 \\
\hline Litvánia & 0,26 & 3,85 & 4,32 & 3,82 & 2,88 \\
\hline Magyarország & 11,38 & 20,82 & 45,98 & 32,24 & 54,12 \\
\hline Marokkó & 0,83 & 1,56 & 2,92 & 3,17 & 2,79 \\
\hline Mexikó & 1,42 & 2,55 & 2,58 & 2,84 & 2,67 \\
\hline Moldovai Köztársaság & 0,41 & 1,92 & 5,40 & 7,37 & 5,14 \\
\hline Mongólia & 0,32 & 0,85 & 4,29 & 10,02 & 23,21 \\
\hline Németország & 0,15 & 0,52 & 2,29 & 1,24 & 1,11 \\
\hline Nicaragua & 0,53 & 2,71 & 4,01 & 4,90 & 7,13 \\
\hline Norvégia & 0,79 & 1,73 & 2,20 & 2,03 & 2,83 \\
\hline Olaszország & 0,30 & 0,34 & 1,02 & 1,14 & 0,97 \\
\hline Oroszország & 0,18 & 0,58 & 1,93 & 3,45 & 2,72 \\
\hline Örményország & 0,25 & 4,19 & 5,88 & 7,83 & 5,93 \\
\hline Panamai Köztársaság & $-0,22$ & 5,84 & 6,41 & 7,90 & 9,42 \\
\hline Paraguayi Köztársaság & 0,96 & 1,35 & 1,22 & 0,78 & 1,24 \\
\hline Peru & 1,58 & 3,27 & 3,49 & 4,55 & 4,96 \\
\hline Portugália & 1,68 & 1,41 & 3,00 & 2,17 & 2,37 \\
\hline Románia & 0,27 & 1,62 & 4,90 & 6,30 & 3,62 \\
\hline Salvador & 0,34 & 2,36 & 2,98 & 3,65 & 2,41 \\
\hline Sierra Leone & $-0,98$ & 0,02 & 1,71 & 3,35 & 13,10 \\
\hline Spanyolország & 1,49 & 1,75 & 3,89 & 3,14 & 2,56 \\
\hline Sri Lanka & 0,88 & 1,11 & 1,04 & 1,28 & 1,26 \\
\hline Svédország & 1,01 & 5,38 & 6,86 & 4,42 & 3,15 \\
\hline Szlovák Köztársaság & 2,09 & 3,69 & 10,74 & 7,46 & 2,69 \\
\hline Szlovénia & 0,76 & 0,78 & 2,11 & 1,73 & 1,07 \\
\hline Tádzsikisztán & 0,43 & 1,16 & 5,75 & 9,12 & 5,76 \\
\hline Thaiföld & 1,70 & 1,92 & 3,76 & 3,42 & 2,48 \\
\hline Törökország & 0,26 & 0,34 & 0,54 & 1,99 & 1,96 \\
\hline Tunézia & 1,99 & 2,31 & 2,62 & 4,37 & 3,99 \\
\hline Türkmenisztán & 2,95 & 5,34 & 3,51 & 6,94 & 11,94 \\
\hline Új-Zéland & 2,57 & 3,35 & 2,06 & 1,21 & 1,75 \\
\hline Ukrajna & 0,20 & 0,80 & 2,61 & 5,44 & 4,76 \\
\hline Uruguay & 0,62 & 0,58 & 1,06 & 5,47 & 5,32 \\
\hline Venezuela & 1,35 & 3,06 & 2,75 & 1,15 & 0,55 \\
\hline Zimbabwe & 0,15 & 0,94 & 1,00 & 0,63 & 2,00 \\
\hline
\end{tabular}

Forrás: az ENSZ Kereskedelmi és Fejlesztési Konferencia (UNCTAD) adatbázisa (https://unctadstat.unctad.org/EN/). 
8. függelék

A GDP arányában kifejezett külföldi müködőtỏke összállománya (stock) a mintában szereplö országokban

(\%)

\begin{tabular}{|c|c|c|c|c|c|}
\hline & 1990 & 1995 & 2000 & 2005 & 2010 \\
\hline Albánia & $0,93^{a}$ & 8,82 & 7,08 & 12,67 & 27,29 \\
\hline Algéria & 2,53 & 3,98 & 6,18 & 7,97 & 12,12 \\
\hline Amerikai Egyesült Államok & 9,00 & 13,09 & 26,98 & 21,48 & 22,68 \\
\hline Argentína & 5,93 & 10,01 & 21,94 & 27,48 & 20,07 \\
\hline Ausztrália & 24,82 & 28,46 & 29,77 & 32,56 & 40,61 \\
\hline Ausztria & 6,97 & 7,88 & 15,84 & 26,13 & 40,98 \\
\hline Belgium & 28,44 & 39,22 & 82,65 & 98,08 & 98,42 \\
\hline Bolívia & 21,07 & 23,30 & 61,77 & 51,36 & 35,06 \\
\hline Brazília & 9,13 & 6,15 & $15,69^{a}$ & 19,95 & 28,99 \\
\hline Bulgária & 0,54 & 2,35 & 20,41 & 46,43 & 89,29 \\
\hline Chile & 46,13 & 32,54 & 58,39 & 63,92 & 73,63 \\
\hline Costa Rica & 18,23 & 3,56 & 18,79 & 35,96 & 42,76 \\
\hline Cseh Köztársaság & $4,52^{\mathrm{a}}$ & 12,30 & 35,11 & 44,51 & 61,94 \\
\hline Dánia & 6,65 & 12,86 & 44,82 & 27,38 & 29,86 \\
\hline Dél-afrikai Köztársaság & 7,89 & 9,66 & 31,86 & 37,51 & 47,84 \\
\hline Dominikai Köztársaság & 6,00 & $4,57^{\mathrm{a}}$ & 6,98 & 24,97 & 35,35 \\
\hline Ecuador & 10,67 & 14,82 & 34,59 & 23,76 & 17,05 \\
\hline Egyesült Királyság & 18,65 & 14,89 & 26,51 & 31,05 & 43,15 \\
\hline $\begin{array}{l}\text { Egyiptomi Arab } \\
\text { Köztársasáq }\end{array}$ & 30,68 & 22,34 & 20,86 & 30,58 & 34,06 \\
\hline Észak-Macedónia & $2,46^{a}$ & 1,84 & 14,31 & 33,34 & 46,25 \\
\hline Észtország & $1,82^{\mathrm{a}}$ & 15,07 & 46,43 & 79,40 & 78,95 \\
\hline Fehéroroszország & $0,03^{a}$ & 0,35 & 12,12 & 7,63 & 17,31 \\
\hline Finnország & 3,02 & 6,08 & 19,31 & 26,76 & 34,79 \\
\hline Franciaország & 8,20 & 14,53 & 13,50 & 17,24 & 23,82 \\
\hline Fülöp-szigetek & 6,66 & 8,20 & 16,98 & 14,53 & 12,97 \\
\hline Görögország & 5,80 & 8,01 & 10,71 & 11,78 & 11,70 \\
\hline Grúzia & $0,00^{\mathrm{a}}$ & 1,13 & 23,69 & 35,52 & 69,24 \\
\hline Haiti & 4,81 & 1,21 & 2,58 & 3,72 & 9,32 \\
\hline Hollandia & 22,56 & 24,49 & 58,53 & 69,98 & 69,47 \\
\hline Horvátország & $0,92^{\mathrm{a}}$ & 2,21 & 12,30 & 30,00 & 53,86 \\
\hline Iráni Iszlám Köztársaság & 2,12 & 2,00 & 2,33 & 7,07 & 5,90 \\
\hline Írország n & 76,95 & 63,83 & 127,28 & 77,27 & 128,55 \\
\hline Jamaica & 14,98 & 23,84 & 36,83 & 61,53 & 82,11 \\
\hline Japán & 0,31 & 0,62 & 1,03 & 2,12 & 3,77 \\
\hline Kanada & 18,93 & 20,33 & 43,64 & 54,44 & 60,84 \\
\hline Kazahsztán & $4,10^{\mathrm{a}}$ & 14,08 & 55,09 & 44,83 & 55,83 \\
\hline Kína & 5,24 & 13,76 & 15,96 & 11,90 & 9,64 \\
\hline
\end{tabular}

a Az időben legközelebbi, rendelkezésre álló információk alapján, illetve arányositással pótolva.

Forrás: saját számítás az ENSZ Kereskedelmi és Fejlesztési Konferencia (UNCTAD) adatbázisa alapján (https://unctadstat.unctad.org/EN/). 
A GDP arányában kifejezett külföldi müködőtőke összállománya (stock) a mintában szereplő országokban (folytatás)

\begin{tabular}{|c|c|c|c|c|c|}
\hline & 1990 & 1995 & 2000 & 2005 & 2010 \\
\hline Kirgizisztán & $0,39^{\mathrm{a}}$ & 9,67 & 31,52 & 25,49 & 35,41 \\
\hline Kolumbia & 6,21 & 5,86 & 11,28 & 25,48 & 29,01 \\
\hline Koreai Köztársaság & 1,81 & 3,19 & 7,59 & 11,22 & 11,84 \\
\hline $\begin{array}{l}\text { Koreai Népi Demokratikus } \\
\text { Köztársaság }\end{array}$ & 0,04 & 0,27 & 0,50 & 0,79 & 1,15 \\
\hline Lengyelország & 0,17 & 5,52 & 19,48 & 28,21 & 39,14 \\
\hline Lettország & $2,53^{a}$ & 11,42 & 21,31 & 29,02 & 45,66 \\
\hline Litvánia & $1,13^{a}$ & 5,25 & 20,23 & 32,32 & 41,42 \\
\hline Magyarország & 1,53 & 24,34 & 48,43 & 54,09 & 69,41 \\
\hline Marokkó & 9,93 & 13,24 & 22,73 & 33,18 & 48,36 \\
\hline Mexikó & 7,48 & 11,42 & 17,19 & 28,28 & 36,83 \\
\hline Moldovai Köztársaság & $0,46^{a}$ & 4,59 & 29,03 & 34,40 & 42,40 \\
\hline Mongólia & 0,01 & 2,24 & 13,77 & 126,36 & 117,46 \\
\hline Németország & 12,79 & 12,09 & 24,24 & 22,49 & 28,14 \\
\hline Nicaragua & 4,07 & 9,33 & 27,77 & 39,06 & 53,44 \\
\hline Norvégia & 10,34 & 12,37 & 17,67 & 25,62 & 41,36 \\
\hline Olaszország & 5,10 & 5,56 & 10,71 & 12,78 & 15,37 \\
\hline Oroszország & $0,03^{a}$ & 1,39 & 11,37 & 23,15 & 30,15 \\
\hline Örményország & $2,09^{\mathrm{a}}$ & 4,81 & 25,17 & 26,46 & 44,60 \\
\hline Panamai Köztársaság & 36,84 & 35,31 & 57,38 & 64,70 & 70,46 \\
\hline Paraguayi Köztársaság & 6,94 & 6,15 & 13,27 & 9,97 & 11,95 \\
\hline Peru & 4,57 & 10,32 & 21,38 & 20,88 & 29,13 \\
\hline Portugália & 12,20 & 15,74 & 28,93 & 37,31 & 50,97 \\
\hline Románia & 0,00 & 2,18 & 18,57 & 25,78 & 41,33 \\
\hline Salvador & 4,40 & 3,28 & 16,74 & 28,35 & 39,48 \\
\hline Sierra Leone & 27,65 & 20,53 & 32,99 & 18,17 & 18,70 \\
\hline Spanyolország & 12,29 & 17,20 & 26,19 & 33,34 & 44,23 \\
\hline Sri Lanka & 7,23 & 8,47 & 13,09 & 12,43 & 10,91 \\
\hline Svédország & 4,87 & 11,70 & 35,89 & 44,59 & 71,19 \\
\hline Szlovák Köztársaság & $2,49^{\mathrm{a}}$ & 6,47 & 33,64 & 60,36 & 55,81 \\
\hline Szlovénia & $12,15^{\mathrm{a}}$ & 8,47 & 11,77 & 19,49 & 22,15 \\
\hline Tádzsikisztán & $0,39^{a}$ & 3,28 & 15,82 & 0,76 & 21,73 \\
\hline Thaiföld & 9,32 & 10,45 & 24,48 & 32,44 & 40,83 \\
\hline Törökország & 5,38 & 6,41 & 6,89 & 14,24 & 24,41 \\
\hline Tunézia & 56,32 & 55,40 & 53,76 & 52,18 & 71,20 \\
\hline Türkmenisztán & $0,00^{\mathrm{a}}$ & 18,95 & 19,24 & 16,88 & 59,52 \\
\hline Új-Zéland & 17,47 & 40,74 & 44,27 & 38,44 & 40,75 \\
\hline Ukrajna & $0,30^{\mathrm{a}}$ & 1,78 & 11,97 & 19,28 & 38,87 \\
\hline Uruguay & 7,27 & 5,29 & 9,15 & 16,38 & 30,98 \\
\hline Venezuela & 8,22 & 11,01 & 30,29 & 30,59 & 9,17 \\
\hline Zimbabwe & 2,04 & 4,48 & 14,20 & 19,24 & 15,07 \\
\hline
\end{tabular}

a Az időben legközelebbi, rendelkezésre álló információk alapján, illetve arányosítással pótolva.

Forrás: saját számítás az ENSZ Kereskedelmi és Fejlesztési Konferencia (UNCTAD) adatbázisa alapján (https://unctadstat.unctad.org/EN/). 
9. függelék

A GDP arányában kifejezett export a mintában szereplő országokban

$(\%)$

\begin{tabular}{|c|c|c|c|c|c|}
\hline & 1990 & 1995 & 2000 & 2005 & 2010 \\
\hline Albánia & 10,72 & 8,44 & 7,50 & 8,17 & 12,95 \\
\hline Algéria & 20,86 & 24,44 & 40,30 & 44,58 & 35,39 \\
\hline Amerikai Egyesült Államok & 6,57 & 7,61 & 7,58 & 6,87 & 8,47 \\
\hline Argentína & 8,06 & 7,49 & 8,55 & 20,11 & 15,99 \\
\hline Ausztrália & 12,28 & 13,58 & 15,62 & 13,94 & 16,36 \\
\hline Ausztria & 24,71 & 23,95 & 34,32 & 39,62 & 38,93 \\
\hline Belgium & 57,32 & 61,90 & 79,55 & 86,73 & 84,77 \\
\hline Bolívia & 19,03 & 16,39 & 14,64 & 29,60 & 32,58 \\
\hline Brazilia & 7,72 & 5,98 & 8,45 & 13,29 & 9,14 \\
\hline Bulgária & 24,27 & 28,20 & 36,63 & 39,30 & 40,96 \\
\hline Chile & 23,98 & 21,34 & 24,51 & 33,56 & 32,54 \\
\hline Costa Rica & 19,95 & 30,21 & 39,13 & 35,22 & 25,35 \\
\hline Cseh Köztársaság & $28,16^{\mathrm{a}}$ & 36,28 & 47,20 & 57,32 & 64,09 \\
\hline Dánia & 26,67 & 27,52 & 31,17 & 32,19 & 29,95 \\
\hline Dél-afrikai Köztársaság & 20,18 & 17,92 & 21,99 & 20,03 & 24,34 \\
\hline Dominikai Köztársaság & 22,79 & 24,00 & 23,94 & 17,30 & 12,70 \\
\hline Ecuador & 17,82 & 17,64 & 26,89 & 24,33 & 25,15 \\
\hline Egyesült Királyság & 16,93 & 17,74 & 17,18 & 15,14 & 16,80 \\
\hline $\begin{array}{l}\text { Egyiptomi Arab } \\
\text { Köztársaság }\end{array}$ & 7,18 & 5,22 & 5,51 & 13,67 & 12,32 \\
\hline Észak-Macedónia & $35,97^{\circ}$ & 25,58 & 35,06 & 32,61 & 35,63 \\
\hline Észtország & $13,66^{\mathrm{a}}$ & 41,17 & 67,21 & 54,74 & 58,85 \\
\hline Fehéroroszország & $25,86^{\mathrm{a}}$ & 33,53 & 68,02 & 51,16 & 44,18 \\
\hline Finnország & 18,79 & 30,18 & 36,58 & 31,98 & 27,90 \\
\hline Franciaország & 17,09 & 18,82 & 23,94 & 21,06 & 19,78 \\
\hline Fülöp-szigetek & 16,53 & 21,31 & 47,00 & 40,03 & 25,80 \\
\hline Görögország & 8,28 & 8,07 & 8,90 & 6,97 & 9,34 \\
\hline Grúzia & $2,21^{\mathrm{a}}$ & 5,31 & 10,04 & 12,83 & 13,70 \\
\hline Haiti & 5,18 & 4,09 & 8,67 & 11,62 & 8,63 \\
\hline Hollandia & 41,40 & 44,92 & 55,84 & 59,32 & 67,83 \\
\hline Horvátország & $30,83^{\circ}$ & 20,15 & 20,45 & 19,33 & 19,74 \\
\hline Iráni Iszlám Köztársaság & 20,03 & 16,05 & 25,75 & 24,84 & 20,63 \\
\hline Írország & 48,10 & 64,59 & 77,34 & 51,81 & 52,44 \\
\hline Jamaica & 21,95 & 21,69 & 14,38 & 13,62 & 10,04 \\
\hline Japán & 9,18 & 8,13 & 9,81 & 12,51 & 13,50 \\
\hline Kanada & 21,41 & 31,72 & 37,14 & 30,73 & 23,96 \\
\hline Kazahsztán & $16,36^{\mathrm{a}}$ & 25,53 & 48,18 & 48,75 & 40,51 \\
\hline Kína & 15,74 & 20,26 & 20,57 & 33,33 & 25,92 \\
\hline
\end{tabular}

a Az időben legközelebbi, rendelkezésre álló információk alapján, illetve arányositással pótolva.

Forrás: saját számitás az ENSZ Kereskedelmi és Fejlesztési Konferencia (UNCTAD) adatbázisa alapján (https://unctadstat.unctad.org/EN/). 
A GDP arányában kifejezett export a mintában szereplő országokban (folytatás)

\begin{tabular}{|c|c|c|c|c|c|}
\hline & 1990 & 1995 & 2000 & 2005 & 2010 \\
\hline Kirgizisztán & $19,33^{a}$ & 27,41 & 37,29 & 27,31 & 36,62 \\
\hline Kolumbia & 11,92 & 9,27 & 13,18 & 14,60 & 13,88 \\
\hline Koreai Köztársaság & 22,69 & 21,92 & 29,90 & 30,42 & 40,77 \\
\hline $\begin{array}{l}\text { Koreai Népi Demokratikus } \\
\text { Köztársaság }\end{array}$ & 12,63 & 19,78 & 6,67 & 10,27 & 18,32 \\
\hline Lengyelország & 21,70 & 16,11 & 18,47 & 29,22 & 33,32 \\
\hline Lettország & $17,45^{a}$ & 24,21 & 23,55 & 30,52 & 40,05 \\
\hline Litvánia & $33,65^{a}$ & 40,36 & 33,01 & 45,16 & 56,02 \\
\hline Magyarország & 26,89 & 27,70 & 59,71 & 55,71 & 72,81 \\
\hline Marokkó & 14,07 & 17,77 & 19,10 & 17,89 & 19,06 \\
\hline Mexikó & 13,57 & 22,09 & 23,50 & 24,41 & 28,20 \\
\hline Moldovai Köztársaság & $21,25^{a}$ & 35,13 & 30,53 & 30,42 & 22,10 \\
\hline Mongólia & 38,52 & 28,21 & 40,65 & 36,40 & 40,33 \\
\hline Németország & 23,77 & 20,25 & 28,33 & 34,12 & 37,07 \\
\hline Nicaragua & 9,30 & 11,32 & 17,29 & 26,25 & 37,12 \\
\hline Norvégia & 28,42 & 27,62 & 35,07 & 33,59 & 30,47 \\
\hline Olaszország & 14,48 & 19,90 & 21,03 & 20,09 & 20,96 \\
\hline Oroszország & $11,37^{\mathrm{a}}$ & 20,49 & 40,16 & 31,60 & 26,02 \\
\hline Örményország & $8,83^{a}$ & 19,74 & 14,43 & 18,64 & 10,24 \\
\hline Panamai Köztársaság & 5,51 & 6,80 & 7,28 & 44,86 & 37,32 \\
\hline Paraguayi Köztársaság & 15,92 & 19,34 & 23,95 & 27,88 & 23,88 \\
\hline Peru & 11,26 & 10,29 & 13,44 & 22,83 & 24,27 \\
\hline Portugália & 20,86 & 19,29 & 20,54 & 19,35 & 20,77 \\
\hline Románia & 12,22 & 21,01 & 27,81 & 28,12 & 29,83 \\
\hline Salvador & 12,08 & 18,52 & 24,96 & 23,25 & 24,39 \\
\hline Sierra Leone & 15,65 & 3,59 & 1,51 & 9,60 & 13,24 \\
\hline Spanyolország & 10,35 & 15,92 & 19,26 & 16,70 & 17,91 \\
\hline Sri Lanka & 20,36 & 24,83 & 28,38 & 22,72 & 15,16 \\
\hline Svédország & 22,16 & 30,31 & 33,26 & 33,60 & 32,01 \\
\hline Szlovák Köztársaság & $31,26^{a}$ & 42,81 & 57,11 & 65,04 & 71,70 \\
\hline Szlovénia & $41,90^{\mathrm{a}}$ & 38,95 & 43,22 & 53,16 & 60,63 \\
\hline Tádzsikisztán & $7,48^{\mathrm{a}}$ & 61,57 & 91,21 & 39,31 & 21,19 \\
\hline Thaiföld & 26,08 & 33,34 & 54,56 & 58,60 & 56,67 \\
\hline Törökország & 6,25 & 9,27 & 10,18 & 14,65 & 14,75 \\
\hline Tunézia & 26,09 & 27,66 & 27,24 & 32,52 & 37,29 \\
\hline Türkmenisztán & $45,57^{\mathrm{a}}$ & 85,84 & 50,81 & 34,86 & 28,78 \\
\hline Új-Zéland & 20,67 & 21,61 & 24,42 & 18,94 & 21,42 \\
\hline Ukrajna & $13,20^{\mathrm{a}}$ & 26,06 & 45,01 & 38,36 & 37,85 \\
\hline Uruguay & 18,32 & 9,88 & 10,05 & 19,71 & 16,69 \\
\hline Venezuela & 37,20 & 24,65 & 28,62 & 38,29 & 16,69 \\
\hline Zimbabwe & 12,62 & 19,17 & 22,07 & 25,73 & 26,57 \\
\hline
\end{tabular}

${ }^{a}$ Az időben legközelebbi, rendelkezésre álló információk alapján, illetve arányositással pótolva.

Forrás: saját számitás az ENSZ Kereskedelmi és Fejlesztési Konferencia (UNCTAD) adatbázisa alapján (https://unctadstat.unctad.org/EN/). 